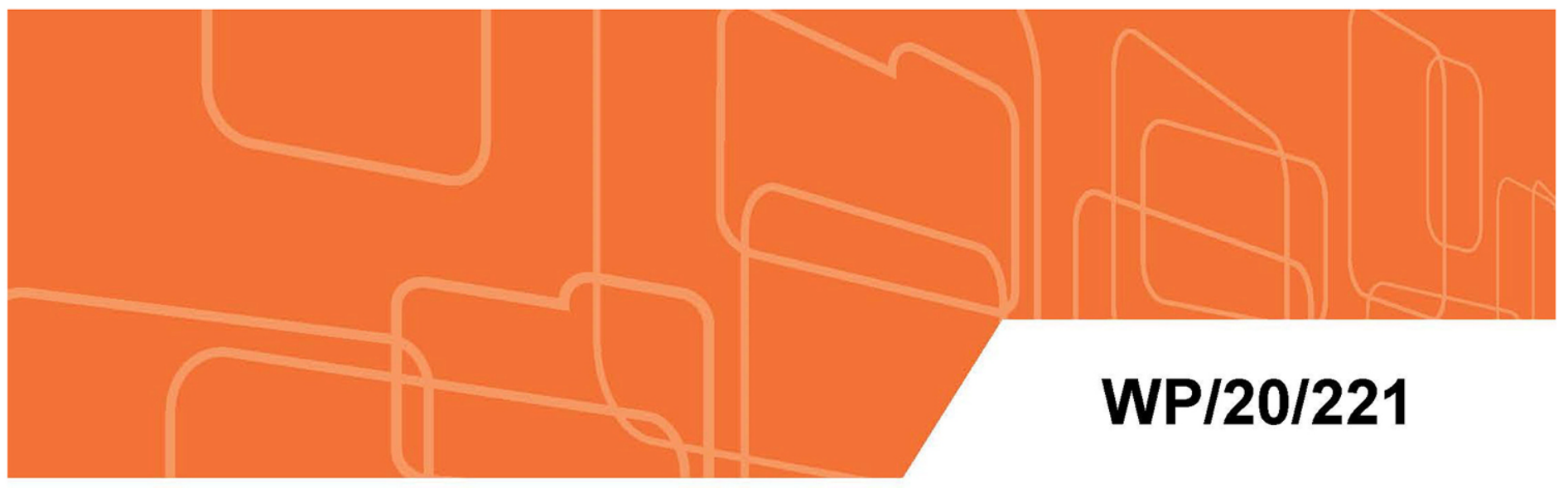

IMF Working Paper

\title{
The Economic Consequences of Conflict in Sub-Saharan
} Africa

By Xiangming Fang, Siddharth Kothari, Cameron McLoughlin, and Mustafa Yenice

IMF Working Papers describe research in progress by the author(s) and are published to elicit comments and to encourage debate. The views expressed in IMF Working Papers are those of the author(s) and do not necessarily represent the views of the IMF, its Executive Board, or IMF management.

I N T E R N A T I O N A L M O N E T A R Y F U N D 


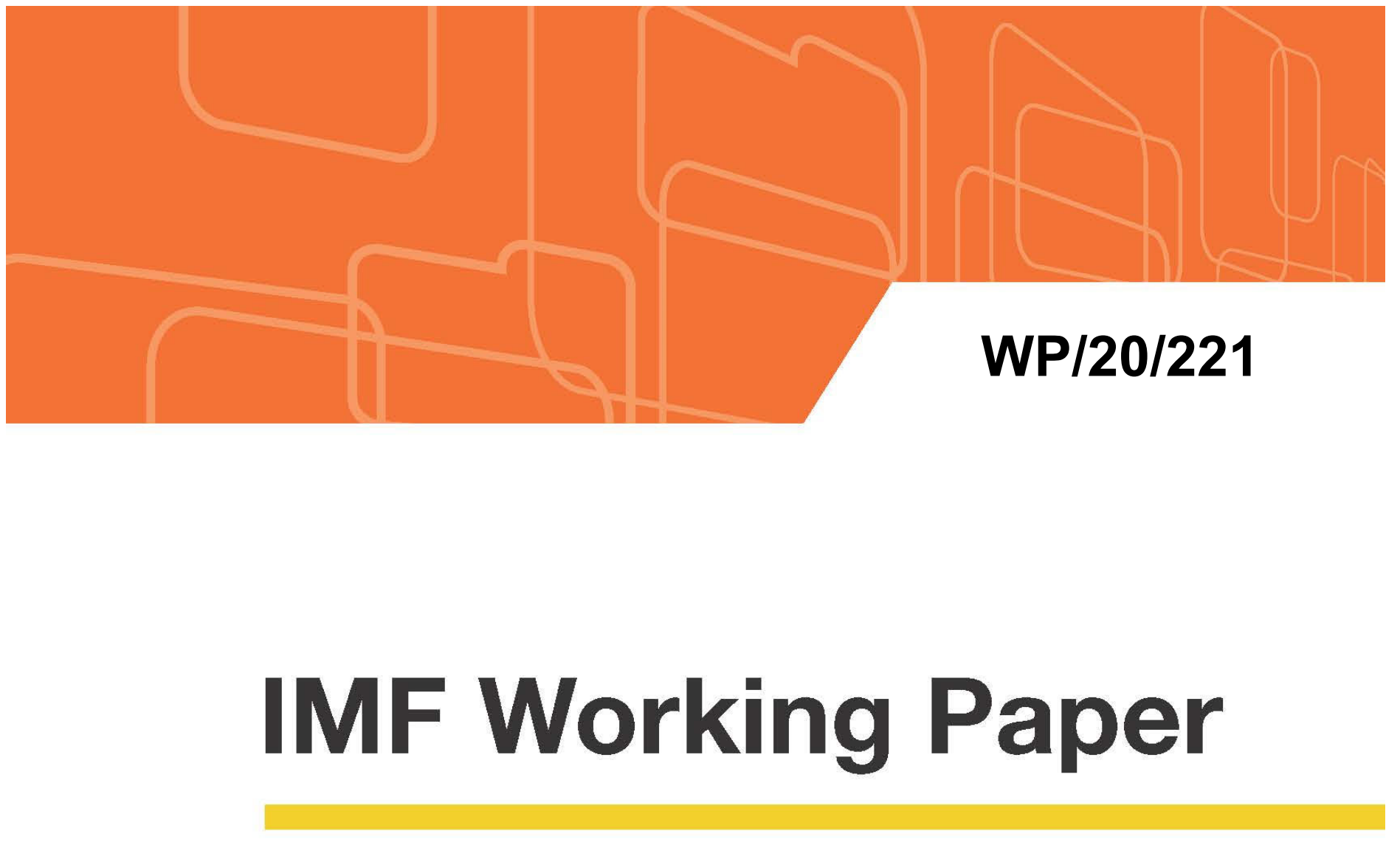

\section{The Economic Consequences of Conflict in Sub-Saharan Africa}

By Xiangming Fang, Siddharth Kothari, Cameron McLoughlin, and Mustafa Yenice

IMF Working Papers describe research in progress by the author(s) and are published to elicit comments and to encourage debate. The views expressed in IMF Working Papers are those of the author(s) and do not necessarily represent the views of the IMF, its Executive Board, or IMF management.

$$
\text { I N T E R N A T I O N A L M O N E T A R Y F U N D }
$$




\title{
IMF Working Paper
}

\author{
African Department \\ The Economic Consequences of Conflict in Sub-Saharan Africa \\ Prepared by Xiangming Fang, Siddharth Kothari, Cameron McLoughlin, and Mustafa \\ Yenice $^{1}$
}

Authorized for distribution by Papa N'Diaye

October 2020

\begin{abstract}
IMF Working Papers describe research in progress by the author(s) and are published to elicit comments and to encourage debate. The views expressed in IMF Working Papers are those of the author(s) and do not necessarily represent the views of the IMF, its Executive Board, or IMF management.
\end{abstract}

\begin{abstract}
Sub-Saharan Africa has been marred by conflicts during the past several decades. While the intensity of conflicts in recent years is lower than that observed in the 1990s, the region remains prone to conflicts, with around 30 percent of the countries affected in 2019 . In addition to immeasurable human suffering, conflicts impose large economic costs. On average, annual growth in countries in intense conflicts is about 2.5 percentage points lower, and the cumulative impact on per capita GDP increases over time. Furthermore, conflicts pose significant strains on countries' public finances, lowering revenue, raising military spending, and shifting resources away from development and social spending.

JEL Classification Numbers: O23, O47, O57

Keywords: conflict, growth, fiscal policy, military spending, sub-Saharan Africa

Author’s E-Mail Address: xfang@,imf.org; skothari@,imf.org; cmcloughlin@,imf.org
\end{abstract}

\footnotetext{
${ }^{1}$ We are grateful to Mahvash Saeed Qureshi, David Robinson, and Papa N'Diaye for their helpful guidance and comments.
} 


\section{INTRODUCTION}

Armed conflict in its various forms and manifestations remains pervasive around the world. ${ }^{2}$ In sub-Saharan Africa, while a declining trend was observed in the incidence and intensity of conflicts since the early 2000 s, there has been an uptick in violence in recent years that mirrors the global increase in conflict. Overall, about a third of the countries in the region have been affected by conflict in recent years. As history has repeatedly shown, conflicts impose immeasurable human suffering and large economic and social costs. The loss of human life; destruction of infrastructure, human capital, and institutions; political instability; and greater uncertainty associated with conflicts can impede investment and economic growth - not only during conflict but also afterward, making it difficult to escape the "conflict trap." 3 In addition, conflicts tend to complicate public finances, lowering revenue by destroying part of the tax base while raising military expenditures amd public debt.

Against this backdrop, this paper explores the economic consequences of conflict in subSaharan Africa by focusing on three key questions: 1) how have the prevalence and intensity of conflict evolved over time; 2) what is the impact of conflict on economic growth; and 3) what are the fiscal implications of conflict.

The analysis, based on a sample of 45 sub-Saharan African countries during 1989-2019, shows that after peaking in the late 1990s, the number of conflict incidents and deaths in the region fell substantially during the 2000s. Since 2010, however, there has been a resurgence in conflict-related deaths, especially in the Sahel region - although they remain below the levels observed in the 1990s. Moreover, the nature of conflicts has also changed in recent years, with traditional civil wars being largely replaced by non-state-based conflicts, including the targeting of civilians through terrorist attacks.

The findings presented in this paper show that the economic impact of conflict in subSaharan Africa is large and persistent. Results from growth regressions show that on average, annual growth in countries in conflict is about 2.5 percentage points lower, and the cumulative impact on per capita GDP increases over time. This effect can be attributed mostly to intense conflicts (that is, those in the top quartile in terms of conflict-related-deaths per million people). Given the intensity of conflicts, however, those affecting the key economic/commercial hubs within a country have a larger effect on macroeconomic growth than those located in the periphery. The effect of conflict also appears to be conditional on certain macroeconomic characteristics, with stronger institutions and fiscal fundamentals helping to mitigate the adverse economic impact of conflict.

Moreover, conflicts lead to a persistent decline in the productive capacity of an economy. Results from the local projection method suggest that an increase in conflict intensity to the top quartile reduces per-capita GDP by about $43 / 4$ percent relative to trend in the first year, with the negative effect growing to almost 6.5 percent in the next 4 years. Counterfactual

\footnotetext{
2 This paper uses a broad definition of conflict based on the Uppsala Georeferenced Event Dataset, which includes civil wars and terrorist incidents. Criminal activity is usually excluded. See Section II for data-related details.

3 "Conflict trap" refers to the vicious cycle between conflicts and economic performance, whereby conflicts retard economic growth and development, in turn raising the likelihood of a conflict (Collier and Sambanis, 2002).
} 
analysis based on event studies around large conflict episodes confirm the large and persistent impact of conflict on real GDP per capita.

In tandem with growth, public finances also deteriorate significantly following conflicts, with tax revenues falling, on average, by about 2 percent of GDP in intensive conflict cases relative to no-conflict cases. ${ }^{4}$ While, on average, the findings do not suggest a statistically strong effect of conflicts on total public spending, the composition of spending tilts away from capital expenditure toward military spending. Consequently, the fiscal balance deteriorates and there is a sharp increase in public debt over the conflict period.

The macroeconomic consequences of conflict have been studied extensively in the literature. Collier (1999) highlighted the negative effect of conflict on growth, particularly focusing on the effect on productive capacity through the destruction of capital stock and the reallocation of economic activity from investment spending towards government spending. Several other papers have also focused on the aggregate economic effects of conflict (Blomberg et al. 2004; Rother et al. 2016). The economic impact of conflict also depends on its duration and intensity (Mueller and Tobias, 2016). Morevover, conflict can affect economic development beyond the conflict period and cause significant long-term output loss (Mueller et al. 2017; Novta and Pugacheva, 2020). In addition to the growth impact, some paper focus on the fiscal cost of conflict. Gupta et al. (2004) and Cevik and Ricco (2015) show that armed conflict not only has adverse effects on tax revenues, but also changes the composition of government spending through the increase in defense spending. The findings in Barrett (2018) also underscore the considerable fiscal loss caused by an extended major conflict.

A related starnd of the literature studied outcomes at sub-national or regional levels as conflicts have potential spillover effects. Conflicts can spread to neighboring states - a direct spillover effect (Hegre and Sambanis, 2006). They can also have indirect spillover effects by depressing economic activity (for instance, due to increased uncertainty or trade disruption) or by creating social strains (for example, due to a large influx of refugees) in nearby countries, even if those countries remain uninvolved in the conflict (Murdoch and Sandler, 2002; Gomez and others, 2010; Qureshi, 2013; Rother et al. 2016).

This paper contributes to the existing literature by focusing on sub-Saharan Africa countries. While there is a vast literature on armed conflict in recent years, very few looks at the subSaharan Africa, one of the most affected regions by violent conflicts. This paper constructs a comprehensive measures of conflict using highly disaggregated event level data, documents the evolution of conflict in the region, quantifies the economic cost of conflicts using various methodologies, and sheds some light on policy options to mitigate the impact and prevent conflict.

The rest of the paper is organized as follows: Section II describes the conflict databases we use; Section III presents stylized facts regarding the prevalence and intensity of conflicts in the region; Section IV quantifies the impact of conflicts on economic growth; Section V examines the effects on public finances; and Section VI concludes.

\footnotetext{
${ }^{4}$ As GDP also contracts significantly during conflicts, real tax revenues fall by about 10 percent.
} 


\section{Data ANd Measurement of Conflict}

The primary source of data on conflicts for this paper is the Uppsala Georeferenced Event Dataset (GED) compiled by the Uppsala Conflict Data Program (UCDP). While several conflict datasets are available, this dataset has the advantage that it provides comprehensive information on conflict-related deaths covering the entire world at a geographically disaggregated level. In addition to the GED, we also use information from the Uppsala Armed Conflict Dataset (ACD) to supplement our analysis.

\section{Uppsala Georeferenced Event Dataset (GED)}

The GED is a highly disaggregated dataset which provides information on conflict-related fatalities at the "event" level—where an event is defined as "an incident where armed force was used by an organized actor against another organized actor, or against civilians, resulting in at least 1 direct death at a specific location and a specific date." Criminal violence (including homicides and gang violence) is usually excluded from the dataset as it is often not possible to definitively attribute these events to specific organized groups. The dataset provides information on the number of deaths in each event, as well as the location of the event (latitude and longitude). It covers the period 1989-2019 and includes information on all countries in the world. For the analysis in this paper, the event level dataset is aggregated to the country level to construct a measure of the total number of conflict-related deaths in each year. ${ }^{5}$

\section{Uppsala Armed Conflict Dataset (ACD)}

To check the robustness of the results presented in the paper, the GED is supplemented with the Uppsala Armed Conflict Dataset (ACD), which provides information on conflict-related deaths for all countries starting in 1946. The unit of analysis in this dataset is an "armed conflict"- - defined as "a contested incompatibility that concerns government and/or territory where the use of armed force between two parties, of which at least one is the government of a state, results in at least 25 battle-related deaths in a calendar year." A country can have several conflicts ongoing at the same time if the government has "incompatibility" with multiple organized groups.

Compared to GED, the ACD has a longer time series dimension but covers only state-based conflicts and contains less precise information on the number of conflict-related deaths. In particular, while GED can be used to determine the number of conflict-related deaths in any country, ACD only contains a discrete variable that distinguishes between minor conflicts (25 to 1000 conflict-related deaths; assigned a value of one) and major conflicts (greater than 1000 conflict-related deaths; assigned a value of two). ${ }^{6}$

\footnotetext{
${ }^{5}$ While the exact number of conflict-related deaths is often difficult to ascertain and may be underreported, especially for widespread and persistent conflicts, the GED is the best available source for comparable data for a wide range of countries and a long time period.

${ }^{6}$ Since the unit of analysis in the ACD is an "armed conflict", we aggregate the data to country-year level for the regression analysis by summing the intensity variable across all ongoing conflicts for each country-year.
} 


\section{Conflicts in Sub-Saharan Africa: Stylized FaCtS}

Sub-Saharan Africa has been marred by conflicts during the past several decades, though their intensity, nature, and geographic distribution have varied over time. This section documents stylized facts regarding the prevalence, intensity, geographical distribution and persistence of conflict. Throughout, a country is classified to be in conflict in a particular year if it experienced at least 25 conflict-related-deaths based on the GED. ${ }^{7}$

The region was particularly prone to conflicts in the $1990 \mathrm{~s}$, with the number of conflictridden countries averaging about 15 during 1990-99 (about 35 percent of the total number of countries in the region; Figure 1). Following the declining global trend, the average number of countries affected by conflict in the region dropped to nine during 2004-12. However, that trend has reversed in recent years, with the number of countries in conflict reaching a peak of 18 in 2016 (Figure 2). ${ }^{8}$

\section{Figure 1. Selected Regions: Share of Countries in Conflict}

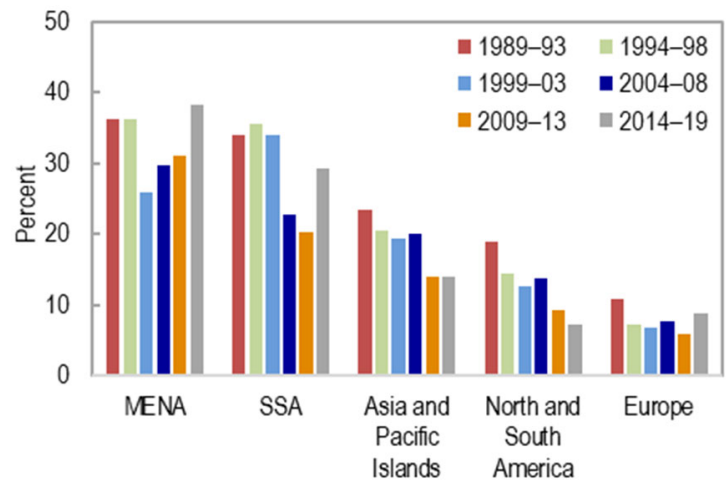

Sources: Uppsala Georeferenced Event Dataset; IMF staff calculations. Note: The figure shows the share of country-years in conflict in each time period. MENA = Middle East and North Africa, SSA = sub-Saharan Africa
Figure 2. Number of Countries in Conflict

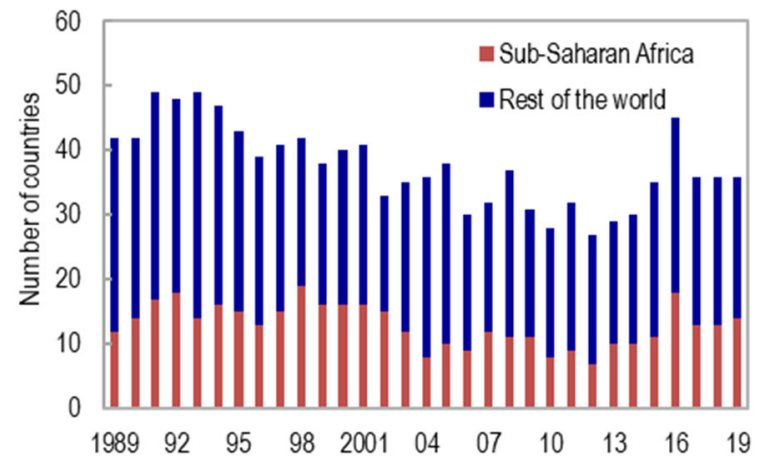

Sources: Uppsala Georeferenced Event Dataset; IMF staff calculations. Note: Country classified to be in conflict if it had at least 25 conflict-related deaths

Conflicts in sub-Saharan Africa have been particularly deadly. Estimates based on the GED suggest that in the 1990s alone, verified conflict-related deaths totaled at least 825,000 (over two-thirds of global conflict deaths). The high death toll was driven by the genocide against the Tutsi in Rwanda; the Ethiopian-Eritrean war; and protracted violence in Angola, the Democratic Republic of the Congo, Liberia, and Sierra Leone. As several of these conflicts ended in the early 2000 s, the number of conflict-related deaths in the region fell sharply, reaching its lowest level of about 2,400 deaths in 2010. A resurgence in violence in recent years, however, implies an increase in conflict-related deaths, which have averaged about 14,000 a year since 2014 (a significant number, though well below the average of 84,000

\footnotetext{
${ }^{7}$ A threshold of 25 deaths has been used extensively in the literature, including by the Uppsala Conflict Data Program. See Sundberg and Melander (2013) for details.

${ }^{8}$ The decline in conflict in the region during the 2000s has been attributed to several factors, including the end of the Cold War and stronger conflict-reduction mechanisms, especially international peacekeeping and regional diplomacy (see Straus, 2012).
} 
seen during the 1990s; Figure 3). This rise mirrors the global trend of an increase in conflictrelated deaths, driven largely by violence in the Middle East, especially in Syria.

The number of conflict-related deaths in relation to total population-a measure of conflict intensity - also shows a varying trend over time. In eight sub-Saharan African countries, on average, the ratio of conflict-related deaths to population was in the top quartile of the world distribution in the 1990s, but the number of countries in the region experiencing such intense conflict had fallen to one by 2010 . Yet deadly conflicts have reemerged recently: since 2013, about five countries have (on average) experienced intense conflict that places them in the top quartile (including Central African Republic, Democratic Republic of the Congo, South Sudan, and several Sahel countries; Figure 4).

Figure 3. Total Conflict-Related Deaths



Sources: Uppsala Georeferenced Event Dataset, and IMF staff calculations. Note: Based on verified fatalities. To the extent that news reports and historical sources miss conflict events, estimates may be a lower bound. MENA = Middle East and North Africa.

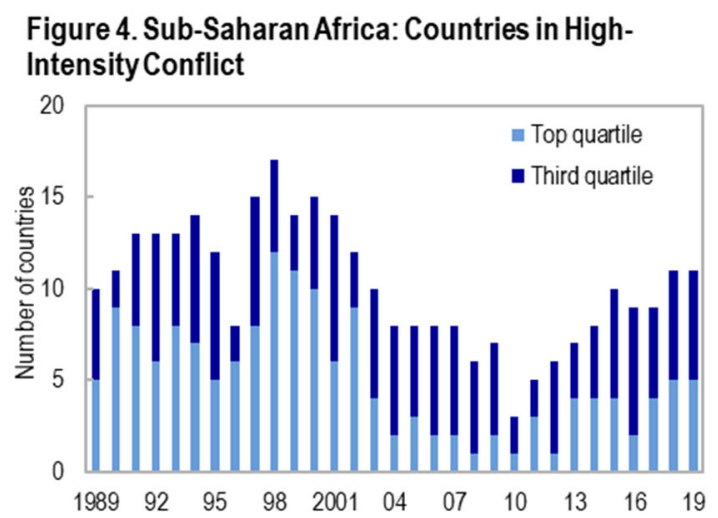

Sources: Uppsala Georeferenced Event Dataset, and IMF staff calculations Note: Countries binned into quartiles based on the world distribution of conflictrelated deaths as a share of population (among confict countries). The top quartile correspond to about 29 conflict-related deaths per million.

\section{Distribution of Conflicts}

Across the region, there has been some changes in the geographic distribution of conflicts over time. Southern Africa has become relatively peaceful since the turn of the century, but conflict remains widespread elsewhere (Table 1). Among the different types of countries (resource-intensive and non-resource-intensive countries), conflict continues to be more prevalent among oil exporters and least prevalent among non-resource-intensive countries.

Although the overall prevalence of conflict in the 2000s has declined across regions and country groups compared with the 1990 s, the Sahel region has experienced a significant increase in violence in the post-2000 period, especially since 2010 (Figure 5). ${ }^{9}$

\footnotetext{
${ }^{9}$ In this paper, the Sahel region is defined as including Burkina Faso, Cameroon, Chad, Mali, Niger, and Nigeria.
} 
Table 1 Sub-Saharan Africa: Share of Countries in Conflict by Geographic Region and Economic Classification

\begin{tabular}{lcc}
\hline 1. Geographic Regions & & \\
\hline \multicolumn{1}{l}{ Central Africa } & 42.4 & Post 2000 \\
Eastern Africa & 35.2 & 28.2 \\
Western Africa & 35.2 & 25.3 \\
Southern Africa & 20.0 & 1.0 \\
\hline 2. By Resource Intensity & & \\
\hline & Pre 2000 & Post 2000 \\
\hline Oil exporters & 52.0 & 42.3 \\
Other resource-intensive countries & 35.2 & 26.0 \\
Non-resource-intensive countries & 29.3 & 20.9 \\
\hline
\end{tabular}

Sources: Uppsala Georeferenced Event Dataset, and IMF staff calculations. Note: Table shows percent of country-years in conflict in a group. See Annex Table 2. for country classifications.
Figure 5. Number of Conflict-Related Deaths in Sahel Region

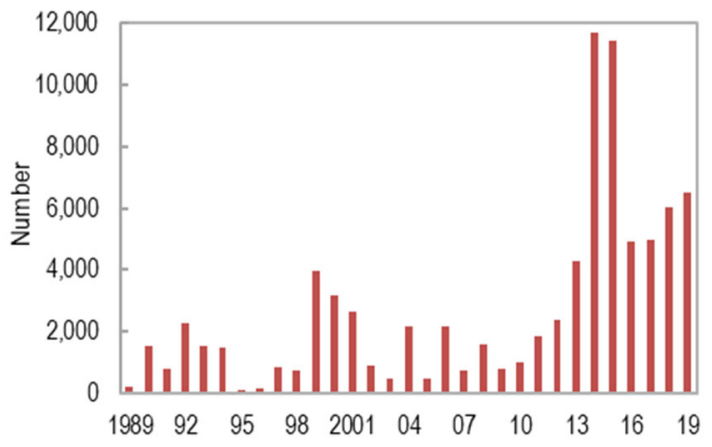

Sources: Uppsala Georeferenced Event Dataset, and IMF staff calculations.

\section{Nature of Conflict}

In principle, conflicts can be differentiated along several dimensions - for example, the actors involved (state versus nonstate), motivation (religious, political, ethnic), location (domestic versus international, center versus periphery), and so on. In practice, however, the classifications are often not mutually exclusive and tend to involve some subjective judgment. Moreover, the information needed for classification purposes may also be lacking.

Notwithstanding these limitations, this paper uses the available information on conflicts involving the state and those not involving the state (but involving other organized armed groups) to differentiate between the types of conflict. In particular, the GED distinguishes between three types of conflicts: (i) statebased, which involve violence between two organized groups where at least one party is the government; (ii) nonstate-based, which occur between two organized groups, neither of which is a government; and (iii) one-sided events where an organized group, which could be the government or a non-government actor, targets civilians. Since most of one-sided conflicts in sub-Saharan Africa involve nonstate-based actors, the categories (ii) and (iii) are combined and referred to as nonstate-

Figure 6. Sub-Saharan Africa: Conflict-Related Deaths in Different Types of Conflicts

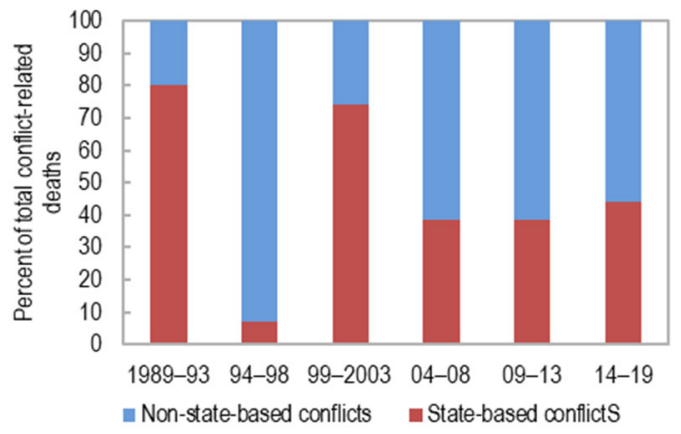

Sources: Uppsala Georeferenced Event Dataset, and IMF staff calculations. Note: The period 1994-98 includes the genocide of the Tutsi in Rwanda which is classified as non-state-based as it targeted civilians. based conflicts for the analysis done in the paper. 
State-based conflicts such as those in Angola, Eritrea, Ethiopia, and Sierra Leone largely drove developments in conflict-related deaths in sub-Saharan Africa during the pre-2000 period (Figure 6). Since then, however, the share of non-state-based conflict deathsbroadly defined to include conflicts between two nongovernmental armed groups, as well as violent events, such as terrorist attacks in which organized armed groups target civilianshas increased significantly. ${ }^{10}$

\section{Persistence of Conflict}

Conflicts in sub-Saharan Africa tend to be persistent, although there is considerable variation in the duration of conflicts across the region. Although some countries, such as the Democratic Republic of the Congo and Nigeria, have been involved in some form of conflict over most of the sample period (31 years and 29 years, respectively).

However, the persistence of conflicts has generally declined over time: the probability of a country exiting conflict has increased from 20 percent in the pre-2000 period to about 24 percent afterward. This aggregate trend does not hold for the Sahel region though, where conflicts have become substantially more persistent in the post-2000 years (Figure 7).

\section{Population Displacement}

A major consequence of conflicts in sub-Saharan Africa, as well as elsewhere, is the displacement of populations. This carries significant economic, fiscal, and social costs for the region involved in conflict, but often also for the nearby regions that host the displaced people. Over time, the number of (United Nations-recognized) persons of concern from subSaharan African countries-including internally displaced persons, asylum seekers, and refugees - has more than tripled, rising from fewer than 5 million in the 1980s to 18 million in 2017 (Figure 8), with more intense conflicts generally implying larger displaced populations (Figure 9).

\footnotetext{
${ }^{10}$ IMF (2019), using data from the Global Terrorism Database, also shows that there has been an increase in terrorist incidents across sub-Saharan Africa.
} 
Figure 8. Persons of Concern from Sub-Saharan Africa

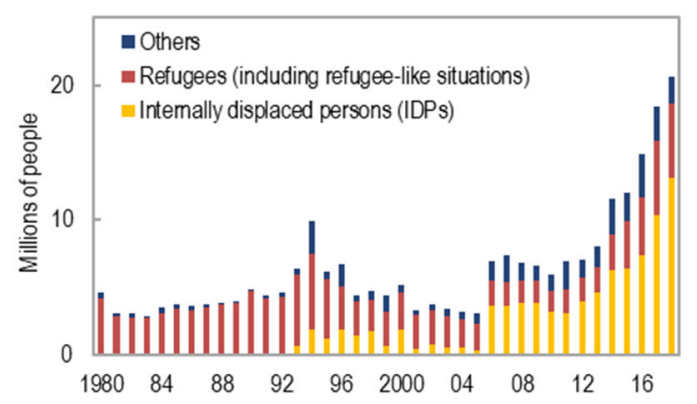

Source: United Nations High Commissioner for Refugees database. Note: Data availabilty for IDPs prior to 2006 is limited. Others include asylum seekers, returned refugees, returned IDPs, stateless persons, others of concern. Figure 9: People of Concern Based on Country of Origin vs.
Number of Conflict-Related Deaths

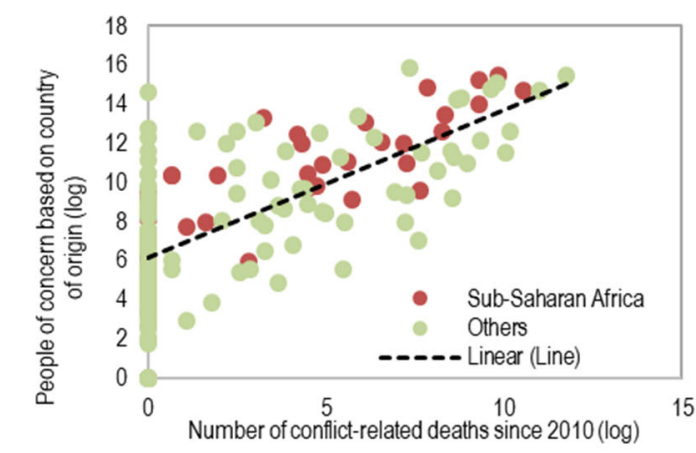

Sources: GED, United Nations High Commissioner for Refugees database, and IMF staff calculations.

Figure 10. Destination of Sub-Saharan African Refugees, 2018

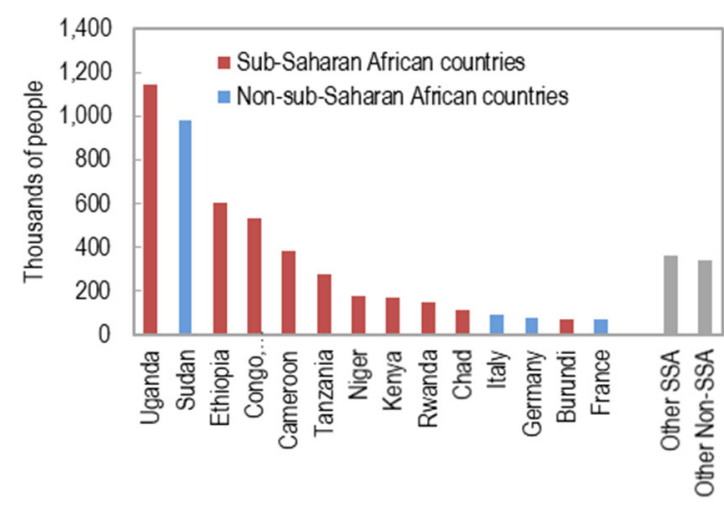

Source: United Nations High Commissioner for Refugees database.

Notably, as of 2017, the majority of the close to 6 million refugees and 1 million asylum seekers who originated in sub-Saharan Africa had resettled within the region; a relatively smaller number have been recorded as refugees in advanced economies (Figure 10). Refugees constituted more than 3 percent of the population of Chad and Uganda in 2017 (only Jordan, Lebanon, and Turkey, following the Syrian crisis, have a higher refugee-to-population ratio). ${ }^{11}$

Similarly, the number of internally displaced people in the region is five times higherrising from fewer than 2 million to 10 million over the past two decades. The Democratic Republic of the Congo (4.4 million), South Sudan (1.9 million), and Nigeria (1.7 million) have the most internally displaced people, comparable to some degree with the numbers for Syria and Iraq in 2017 (6.2 and 2.6 million, respectively).

\footnotetext{
${ }^{11}$ See World Bank (2016) for a detailed study on the refugee management experience in Uganda, including the role of Uganda's progressive refugee laws regarding freedom of movement and access to labor markets for refugees.
} 


\section{CONFLICT AND ECONOMIC GROWTH}

How does conflict affect economic growth in sub-Saharan Africa? A simple comparison of economic growth rates in conflict and nonconflict cases suggests that real GDP growth is, on average, about 2.5 percentage points lower where there is conflict (Figure 11), and growth is lowest in cases of highintensity conflict. Growth tends to be lower in conflict cases across all country groups, but commodity exporters (especially, non-oil commodity exporters) have suffered the most. This reflects in part the intense conflicts in many of these countries (Central African Republic, Democratic Republic of the Congo, Liberia, and Sierra Leone).

\begin{abstract}
Figure 11. Sub-Saharan Africa: Average Growth Rate by Country Type
\end{abstract}

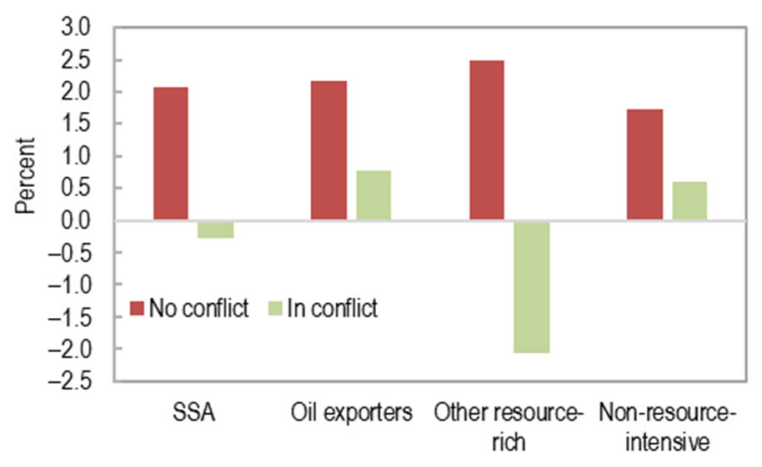

Sources: IMF staff calculations

Note: Country defined to be in conflict if it had 25 or more conflict-related deaths.

To further investigate the impact of conflict on economic growth, this section uses different rigorous empirical techniques - including standard growth regression, impulse responses, and constructing some simple counterfactuals to estimate the loss of output due to conflicts. ${ }^{12}$

\section{Standard Growth Regressions}

Following the existing literature (e.g., Blomberg et al. 2004; Murdoch and Sandler, 2002; Cerra and Saxena, 2008), the impact of conflict on economic growth is estimated using standard growth regressions, as follows:

$$
y_{i, t}-y_{i, t-1}=\beta_{1} y_{i, t-1}+\beta_{2} C_{i, t}+\gamma X_{i, t}+\alpha_{i}+\alpha_{t}+\epsilon_{i, t}
$$

where $y_{i, t}$ is $(\log )$ real per-capita GDP in country $i$ at time $t, C_{i, t}$ is the conflict variable of interest, $X_{i, t}$ is a vector of other control variables (such as the investment rate, trade openness, and export-partner growth), and $\alpha_{i}$ and $\alpha_{t}$ are country-specific and time effects, respectively. ${ }^{13}$ Standard errors are clustered at the country level.

The number of conflict-related deaths relative to (lagged) population is used as a measure of conflict intensity. However, this variable has some extreme outliers (for example, the genocide against the Tutsi in Rwanda in 1994 where about 8 percent of the population perished due to conflict), which may bias the regression results. To address this issue, we construct an alternative variable based on the percentile of the conflict intensity variable in

\footnotetext{
${ }^{12}$ Several studies analyze the effect of conflict on poverty and inequality, generally finding that conflicts increase poverty and inequality (Baranti, Beaudet, and Locher 2011; Bircan, Brück, and Vothknecht, 2017).

${ }^{13}$ Although the fixed-effect model with lagged dependent variable can produce biased estimates ("Nickell Bias" which is of the order $1 / \mathrm{T}$ ), in our case the bias is likely small at about 4 percent ( 25 years of data). Given the small bias, we use the fixed effect model as the baseline but present robustness checks by using GMM methods which corrects for this source of bias.
} 
the world distribution (pooled across countries and years) and use that in the regression analysis. For this measure, the 25th, 50th and 75 th percentiles in the data correspond to conflict-related death rates of $0.75,4.2$, and 25.2 per million people, respectively.

The results for equation (1), using the conflict intensity variable constructed from the GED, are presented in Table 2 . They show that increased violence is robustly associated with lower economic growth. For sub-Saharan Africa, the results imply that increasing conflict intensity from zero (no conflict-related deaths) to the top quartile is associated with a decline in per capita growth rate of 2.6 percentage points (column 1). Conflict is also associated with lower growth in other (non-sub-Saharan African) emerging market and developing countries (column 2). ${ }^{14}$

While the coefficients on the conflict intensity variable in columns (1) and (2) suggest that the impact of conflicts on economic growth is larger for sub-Saharan Africa than for other countries, the difference is not statistically significant (as indicated by the coefficient on the interaction term between conflict intensity and a dummy variable for sub-Saharan Africa in column 3).

The effect of conflicts on growth, however, appears to be conditional on some macroeconomic characteristics - notably, institutional quality and fiscal fundamentals - at the onset of the conflict (column 4). Specifically, an increase in conflict intensity is associated with about 1.5 percentage points lower growth in countries with relatively strong institutions (defined as falling in the top quartile of the distribution of the Institutional Quality Index) compared with 2.5 percentage points where institutions are weaker (in the bottom quartile of the distribution). Similarly, countries with weaker fiscal fundamentals, in terms of higher debt, experience a larger decline in growth, presumably because there is less room to respond to the destruction caused by conflicts (column 5). ${ }^{15}$

\footnotetext{
${ }^{14}$ As the conflict intensity variable is the percentile of conflict-related deaths as a share of population (ranging from 0 to 1 ), the growth effects for an increase in conflict intensity to the $75^{\text {th }}$ percentile is computed by multiplying the coefficient on conflict intensity by 0.75 .

15 The results also show that higher investment rates and trade openness are associated with higher growth rates in subSaharan Africa. An increase in investment from 21 percent of GDP (the median for the region) to 28 percent of GDP (the 75 th percentile for the world distribution) would, on average, stimulate growth by about 0.6 percentage points, while increasing trade openness (in terms of the export and import volume) to the 75th percentile would boost growth by 1.5 percentage points.
} 
Table 2. Impact of Conflict on Growth, Uppsala GED, 1989-2017

\begin{tabular}{|c|c|c|c|c|c|c|c|c|}
\hline & $(1)$ & $(2)$ & (3) & $(4)$ & $(5)$ & $(6)$ & $(7)$ & $(8)$ \\
\hline & & Non-SSA & All EMs \& & All EMs \& & All EMs \& & All EMs \& & All EMs \& & All EMs \& \\
\hline & SSA & EMs\&LIDCS & LIDCs & LIDCs & LIDCs & LIDCs & LIDCs & LIDCs \\
\hline & & & & & & & Diff GMM & Sys GMM \\
\hline \multirow[t]{2}{*}{ Per capita GDP (lagged) } & $-0.042 * * *$ & $-0.046 * * *$ & $-0.042 * * *$ & $-0.038 * * *$ & $-0.046 * * *$ & $-0.046 * * *$ & $-0.041 * * *$ & $-0.021^{* *}$ \\
\hline & $(0.012)$ & $(0.014)$ & $(0.010)$ & $(0.010)$ & $(0.011)$ & $(0.012)$ & $(0.010)$ & $(0.009)$ \\
\hline \multirow[t]{2}{*}{ Conflict intensity } & $-3.468 * * *$ & $-2.897^{*}$ & $-3.289 *$ & $-2.772 * * *$ & $-2.785 * * *$ & $-2.269 * * *$ & $-2.837 * *$ & $-2.799 * *$ \\
\hline & $(0.856)$ & $(1.700)$ & $(1.756)$ & $(1.043)$ & $(0.736)$ & $(0.693)$ & $(1.118)$ & $(1.322)$ \\
\hline \multirow[t]{2}{*}{ SSA $\times$ Conflict intensity } & & & -0.363 & & & & & \\
\hline & & & $(1.863)$ & & & & & \\
\hline \multirow[t]{2}{*}{ Institutional quality $\times$ Conflict } & & & & $1.358^{* *}$ & & & & \\
\hline & & & & $(0.631)$ & & & & \\
\hline \multirow[t]{2}{*}{ Debt x Conflict } & & & & & $-0.025^{*}$ & & & \\
\hline & & & & & $(0.013)$ & & & \\
\hline \multirow[t]{2}{*}{ Center-periphery $\times$ Conflict } & & & & & & $-1.911 * * *$ & & \\
\hline & & & & & & $(0.438)$ & & \\
\hline \multirow[t]{2}{*}{ Investment/GDP } & 0.047 & $0.097 * * *$ & $0.062 * *$ & 0.052 & $0.094 * *$ & $0.101 * * *$ & 0.063 & 0.055 \\
\hline & $(0.041)$ & $(0.032)$ & $(0.031)$ & $(0.032)$ & $(0.038)$ & $(0.032)$ & $(0.044)$ & $(0.053)$ \\
\hline \multirow[t]{2}{*}{ Human capital } & & -1.414 & -1.075 & -2.528 & -0.338 & 1.583 & 0.368 & 2.373 \\
\hline & & $(3.182)$ & $(1.805)$ & $(1.924)$ & $(1.955)$ & $(1.966)$ & (2.499) & (1.448) \\
\hline \multirow[t]{2}{*}{ Trade openness (log) } & $3.764 * *$ & 0.902 & $1.357^{*}$ & 1.367 & 1.135 & 0.571 & 1.496 & 1.008 \\
\hline & $(1.442)$ & $(0.718)$ & $(0.760)$ & $(0.847)$ & $(0.714)$ & (0.609) & $(0.924)$ & $(1.005)$ \\
\hline \multirow[t]{2}{*}{ Terms of trade (pct change) } & 0.002 & -0.055 & -0.027 & -0.033 & -0.006 & 0.005 & 0.021 & 0.016 \\
\hline & $(0.010)$ & $(0.047)$ & $(0.032)$ & $(0.039)$ & $(0.016)$ & $(0.008)$ & $(0.031)$ & $(0.032)$ \\
\hline \multirow[t]{2}{*}{ Export partners growth } & -0.170 & $0.434 * *$ & $0.352 * *$ & $0.378 * *$ & $0.421 * * *$ & $0.334 * * *$ & $0.811 * * *$ & 0.294 \\
\hline & $(0.146)$ & $(0.164)$ & $(0.137)$ & $(0.148)$ & $(0.133)$ & $(0.124)$ & $(0.206)$ & $(0.202)$ \\
\hline \multirow[t]{2}{*}{ Institutional quality } & & & & -0.605 & & & & \\
\hline & & & & $(0.563)$ & & & & \\
\hline \multirow[t]{2}{*}{ Public debt/GDP } & & & & & 0.016 & & & \\
\hline & & & & & $(0.011)$ & & & \\
\hline \multirow[t]{2}{*}{ Center-periphery } & & & & & & $0.386^{*}$ & & \\
\hline & & & & & & $(0.212)$ & & \\
\hline Country fixed effects & Yes & Yes & Yes & Yes & Yes & Yes & Yes & Yes \\
\hline Year effects & Yes & Yes & Yes & Yes & Yes & Yes & Yes & Yes \\
\hline Frequency & Annual & Annual & Annual & Annual & Annual & Annual & 5 Year & 5 Year \\
\hline Observations & 1,120 & 1,527 & 2,473 & 2,206 & 2,378 & 1,897 & 503 & 523 \\
\hline R-squared & 0.257 & 0.274 & 0.234 & 0.247 & 0.257 & 0.288 & & \\
\hline No. of countries & 40 & 56 & 90 & 81 & 90 & 89 & 90 & 90 \\
\hline No. of Instruments & & & & & & & 98 & 104 \\
\hline AR2 Test & & & & & & & 0.446 & 0.536 \\
\hline Hansen Test & & & & & & & 0.522 & 0.572 \\
\hline $\begin{array}{l}\text { Note: Dependent variable is grow } \\
\text { conflict-related deaths as a share } \\
\text { other control variables. Columns } \\
\text { difference and system GMM with } \\
* * \text {, and }{ }^{*} \text { indicate statistical signi }\end{array}$ & $\begin{array}{l}\text { f per-capita } \\
\text { opulation ba } \\
6 \text { are estima } \\
\text { ear averaged } \\
\text { ice at the } 1,5\end{array}$ & $\begin{array}{l}\text { GDP from Pen } \\
\text { sed on the Up } \\
\text { ted using OLS } \\
\text { data. Standar } \\
\text { and } 10 \text { perce }\end{array}$ & $\begin{array}{l}\text { n World TabT } \\
\text { psala Georef } \\
\text { with country } \\
\text { d errors repo } \\
\text { ent level resp }\end{array}$ & $\begin{array}{l}\text { Tes. The inte } \\
\text { ferenced Ev } \\
y \text { and year fix } \\
\text { orted in para } \\
\text { pectively. }\end{array}$ & $\begin{array}{l}\text { nsity of con } \\
\text { ent Dataset. } \\
\text { xed effects. } \\
\text { antheses are }\end{array}$ & $\begin{array}{l}\text { flict variable } \\
\text { See Annex T } \\
\text { Column } 7 \text { an } \\
\text { clustered at }\end{array}$ & $\begin{array}{l}\text { is the perce } \\
\text { Table } 1 \text { for } d \\
\text { d } 8 \text { are estin } \\
t \text { the country }\end{array}$ & $\begin{array}{l}\text { ntile of } \\
\text { details on } \\
\text { mated using } \\
\text { y level. }\end{array}$ \\
\hline
\end{tabular}

Furthermore, conflicts that occur in economic/urban hubs are likely to have a larger impact on aggregate growth as compared to conflicts occurring in peripheral regions in the country (column 6). Specifically, we create a measure of the "centrality" of conflicts within a country, by using night-lights data at the state level, that captures the extent to which 
violence in the country is taking place in regions with a larger share of economic activity, and add this measure along with its interaction with conflict intensity to equation (1). ${ }^{16}$

Comparing two conflicts in the top quartile of the intensity distribution but with different degrees of centrality indicates that growth will be about 1 percentage point lower for a conflict where the centrality measure is one standard deviation above the mean compared to a conflict where the centrality measure is at the mean. ${ }^{17}$

The association between conflict and economic growth is robust to addressing potential endogeneity concerns by instrumenting for the contemporaneous conflict intensity variable with lagged values using the difference-GMM and system-GMM methodologies (as in columns 7 and 8 , respectively).

These results are also robust to considering an alternative conflict intensity variable based on the Uppsala Armed Conflict Dataset (ACD). The results from the ACD, reported in Table 3, show that conflict intensity has a negative effect on growth: moving from no conflict to a high-intensity conflict is associated with about 2 percentage points lower growth in subSaharan Africa (column 1). The negative relation between conflict and growth also holds for non-sub-Saharan African countries, with the results being robust to using difference and system GMM (columns 4-5).

\section{Non-linear Effects}

Conflict may have a non-linear impact on economic growth, with more severe conflicts having a larger effect. Table 4 reports results where the conflict-related deaths to population ratio from the GED is split into different quartiles (the reference group is the non-conflict observations). Growth during low-intensity conflicts (where conflict-related deaths are in the bottom two quartiles) is not significantly different from the non-conflict cases in sub-Saharan Africa. However, for more intensive conflicts, the negative growth effects are significantly larger. Specifically, growth is 2 percentage points lower for conflict intensity in the third quartile relative to the non-conflict case, and about 3 percentage points lower for conflicts in the top quartile (column 1). This result is similar to the one obtained by Rother and others (2016), who also document larger effects for more intensive conflicts in the Middle East and North Africa.

\footnotetext{
${ }^{16}$ The measure is defined as: Center_periphery $y_{c, t}=\sum_{S} \frac{D_{s, c, t}}{D_{C, t}} \frac{N L_{s, c, t-1}}{N L_{C, t-1}}$, where $D_{s, c, t}$ is the number of conflict-related deaths in state ' $\mathrm{s}$ ' in country ' $\mathrm{c}$ ' at time ' $\mathrm{t}$ '; $D_{c, t}$ is the total number of conflict-related deaths in country 'c' at time ' $\mathrm{t}$ '; $N L_{s, c, t}$ is total night-lights in state 's' in country ' $c$ ' at time ' $t$ '; and $N L_{c, t}$ is total night-lights in country ' $c$ ' at time ' $t$ '. This measure will take higher values if conflict-related deaths are concentrated in states that contribute more to economic activity. The variable is standardized to have mean zero and a standard deviation of one.

${ }^{17}$ The difference in growth rates for the two conflicts with intensity $C$ but different centrality measures $c p_{1}$ and $c p_{2}$ is computed as $\gamma_{1}\left(c p_{2}-c p_{1}\right)+\gamma_{2} C\left(c p_{2}-c p_{1}\right)$ where $\gamma_{1}$ and $\gamma_{2}$ are the coefficients on the centrality measure and the interaction term respectively.
} 
Table 3. Impact of Conflict on Growth, Uppsala ACD, 1970-2017

\begin{tabular}{|c|c|c|c|c|c|}
\hline & (1) & (2) & (3) & (4) & (5) \\
\hline & \multirow{3}{*}{ SSA } & Non-SSA & All EMs \& & All EMs \& & All EMs \& \\
\hline & & EMs\&LIDCs & LIDCs & LIDCs & LIDCs \\
\hline & & & & Diff GMM & Sys GMM \\
\hline \multirow[t]{2}{*}{ Per capita GDP (lagged) } & $-0.028 * * *$ & $-0.043^{* * *}$ & $-0.034 * * *$ & $-0.045 * * *$ & $-0.028 * * *$ \\
\hline & $(0.007)$ & $(0.010)$ & $(0.007)$ & $(0.010)$ & $(0.008)$ \\
\hline \multirow[t]{2}{*}{ Conflict intensity } & $-0.892 * *$ & $-0.886 * *$ & $-0.899 * * *$ & $-1.537^{* *}$ & $-0.966 * *$ \\
\hline & $(0.353)$ & $(0.428)$ & $(0.314)$ & $(0.636)$ & $(0.446)$ \\
\hline \multirow[t]{2}{*}{ Investment/GDP } & $0.091 * * *$ & $0.084^{* * *}$ & $0.073^{* * *}$ & $0.069 * *$ & $0.095^{* *}$ \\
\hline & $(0.031)$ & $(0.030)$ & $(0.026)$ & $(0.032)$ & $(0.039)$ \\
\hline \multirow[t]{2}{*}{ Human capital } & & & -1.059 & 1.370 & $4.290 * * *$ \\
\hline & & & $(1.062)$ & (2.361) & $(1.603)$ \\
\hline \multirow[t]{2}{*}{ Trade openness (log) } & $2.630 * * *$ & 0.899 & $1.218^{* *}$ & $1.529 *$ & 0.380 \\
\hline & $(0.746)$ & $(0.553)$ & $(0.499)$ & $(0.828)$ & $(0.847)$ \\
\hline \multirow[t]{2}{*}{ Terms of trade (pct change) } & 0.008 & -0.035 & -0.015 & $0.043^{*}$ & 0.034 \\
\hline & $(0.008)$ & $(0.033)$ & $(0.024)$ & $(0.023)$ & $(0.023)$ \\
\hline \multirow[t]{2}{*}{ Export partners growth } & -0.067 & $0.192 * *$ & $0.203^{* *}$ & $0.621 * * *$ & 0.217 \\
\hline & $(0.128)$ & $(0.082)$ & $(0.079)$ & $(0.184)$ & $(0.210)$ \\
\hline Country fixed effects & Yes & Yes & Yes & Yes & Yes \\
\hline Year effects & Yes & Yes & Yes & Yes & Yes \\
\hline Frequency & Annual & Annual & Annual & 5 Year & 5 Year \\
\hline Observations & 1,432 & 2,148 & 3,135 & 627 & 717 \\
\hline R-squared & 0.210 & 0.244 & 0.211 & & \\
\hline No. of countries & 40 & 64 & 90 & 90 & 90 \\
\hline No. of Instruments & & & & 97 & 91 \\
\hline AR2 & & & & 0.834 & 0.907 \\
\hline Hansen & & & & 0.509 & 0.406 \\
\hline
\end{tabular}

Table 4. Non-linear Effect of Conflict on Growth, 1989-2017

\begin{tabular}{lccc}
\hline & $(1)$ & $\begin{array}{c}(2) \\
\text { Non-SSA }\end{array}$ & $(3)$ \\
& SSA & EMs\&LIDCs & EMs \& LIDCs \\
\hline Per capita GDP (lagged) & $-0.042^{* * *}$ & $-0.049^{* * *}$ & $-0.046^{* * *}$ \\
& $(0.012)$ & $(0.011)$ & $(0.008)$ \\
Excluded group: No conflict & & & \\
$\quad$ Conflict: 1st Quartile & -0.577 & -0.115 & -0.300 \\
& $(0.619)$ & $(0.478)$ & $(0.365)$ \\
\multicolumn{1}{c}{ Conflict: 2nd Quartile } & -0.727 & 0.002 & -0.385 \\
& $(0.500)$ & $(0.661)$ & $(0.421)$ \\
\multicolumn{1}{c}{ Conflict: 3rd Quartile } & $-1.923^{* *}$ & -0.782 & $-1.326^{* *}$ \\
& $(0.754)$ & $(0.793)$ & $(0.558)$ \\
\multicolumn{1}{c}{ Conflict: 4th Quartile } & $-2.964^{* * *}$ & $-2.684^{*}$ & $-2.872^{* * *}$ \\
& $(0.723)$ & $(1.385)$ & $(0.779)$ \\
\hline Country fixed effects & Yes & Yes & Yes \\
Year effects & Yes & Yes & Yes \\
Frequency & Annual & Annual & Annual \\
Observations & 1,120 & 1,720 & 2,840 \\
R-squared & 0.255 & 0.275 & 0.235 \\
No. of countries & 40 & 64 & 104 \\
\hline
\end{tabular}

Note: Dependent variable is growth of per-capita GDP from Penn World Tables. The conflict variable of interest is the quartile of conflictrelated deaths as a share of population with no conflict being the excluded group. Standard control variables (as in Table 3) are included in all regressions although their coefficients have been suppressed to save space. All columns are estimated using OLS with country and year fixed effects. Standard errors reported in parantheses are clustered at the country level. ${ }^{* * *},{ }^{* *}$, and ${ }^{*}$ indicate statistical significance at the 1,5 and 10 percent level respectively.

\section{CInternational Monetary Fund. Not for Redistribution}




\section{Nature of Conflict}

As documented in the paper (Figure 6), there has been a change in the nature of conflicts in sub-Saharan Africa since 2000, with traditional state-based conflicts being largely replaced by non-state and one-sided violence. Table 5 shows that the growth impact of conflicts does not depend on the type of conflict per se, but it is the overall conflict intensity (conflictrelated deaths as a share of population) that matters in determining growth outcomes. Including conflict intensity variables for the three types of conflicts in the model indicates that they have a negative effect on growth of a statistically equivalent magnitude.

Table 5. Impact of Different Conflict Types on Growth, 1989-2017

\begin{tabular}{|c|c|c|c|c|}
\hline & $(1)$ & $(2)$ & (3) & (4) \\
\hline Per capita GDP (lagged) & $\begin{array}{c}-0.040 * * * \\
(0.012)\end{array}$ & $\begin{array}{c}-0.041 * * * \\
(0.011)\end{array}$ & $\begin{array}{c}-0.041 * * * \\
(0.012)\end{array}$ & $\begin{array}{c}-0.041 * * * \\
(0.012)\end{array}$ \\
\hline State based & $\begin{array}{c}-3.067^{* *} \\
(1.302)\end{array}$ & & & $\begin{array}{l}-2.609 * \\
(1.463)\end{array}$ \\
\hline Non-state based & & $\begin{array}{c}-3.088 * * * \\
(0.978)\end{array}$ & & $\begin{array}{c}-2.489 * * \\
(1.022)\end{array}$ \\
\hline One-sided & & & $\begin{array}{c}-2.055^{* *} \\
(0.859)\end{array}$ & $\begin{array}{l}-0.082 \\
(0.956)\end{array}$ \\
\hline Observations & 1,120 & 1,120 & 1,120 & 1,120 \\
\hline R-squared & 0.252 & 0.249 & 0.246 & 0.257 \\
\hline No. of Countries & 40 & 40 & 40 & 40 \\
\hline Test: State $=$ Non-State & & & & 0.936 \\
\hline Test: State $=$ One-Sided & & & & 0.234 \\
\hline Test: Non-State = One-Sided & & & & 0.180 \\
\hline \multicolumn{5}{|c|}{$\begin{array}{l}\text { Note: Dependent variable is growth of per-capita GDP from Penn World Tables. In columns } 1 \\
\text { through } 4 \text {, the percentile (across all conflict types) of deaths to population for each conflict type is } \\
\text { used as the independent variable. Standard control variables (as in Table } 2 \text { ) are included in all } \\
\text { regressions although their coefficients have been suppressed to save space. All columns are } \\
\text { estimated using OLS with country and year fixed effects. Standard errors reported in parantheses } \\
\text { are clustered at the country level. } * * *, * * \text {, and } * \text { indicate statistical significance at the } 1,5 \text { and } 10 \\
\text { percent level respectively. }\end{array}$} \\
\hline
\end{tabular}

\section{Impulse Responses}

To assess the dynamic effects of conflicts on per-capita GDP, the paper uses the local projection method, which involves estimating separate regressions for each time horizon $(h)$ of the form:

$$
\begin{aligned}
y_{i, t+h}-y_{i, t-1} & =\beta_{1}^{h} C_{i, t}^{j}+\sum_{j=1}^{l} \beta_{1, j}^{h} C_{i, t-j}+\sum_{j=1}^{l} \gamma_{1, j}^{h}\left(y_{i, t-j}-y_{i, t-j-1}\right)+\sum_{j=1}^{l} \theta_{j}^{h} X_{i, t-j}^{j}+\alpha_{i}^{h}+\alpha_{t}^{h} \\
& +\epsilon_{i, t}^{h}
\end{aligned}
$$


where $y_{i, t}$ is $\log$ of per-capita GDP, $C_{i, t}$ is the conflict variable, $X_{i, t}^{j}$ is other control variables, and $h$ is the horizon for which the impulse response is to be computed. $\alpha_{i}^{h}$ and $\alpha_{t}^{h}$ are country and time fixed effects, respectively. The coefficient $\beta_{1}^{h}$ directly estimates the impulse response of per-capita GDP for horizon $h$ in response to a shock to the conflict variable. Two lags of GDP growth and the conflict variable are included in all estimations. ${ }^{18}$

The results, presented in Figure 12, show that an increase in conflict intensity to the top quartile of the measure reduces per-capita GDP by about 4.75 percent in the first year, with the negative effect growing to about 6.5 percent over the next four years. Results are qualitatively similar when other control variables (investment as a share of GDP, openness, partner country growth, etc.) are included in the estimations, as well as when the conflict intensity variable based on the ACD is used.



\section{Permanent Output Losses}

Given the adverse impact of conflict on economic growth and social well-being, how large is the output loss in the long term? While it is difficult to predict the counterfactual of output if conflict had not occurred, comparing projected real GDP per capita before the start of a conflict with the actual outcome following the onset of conflict can be illustrative. This paper uses specific, well-identified conflict episodes to compute the cumulative loss in output arising from conflicts, relative to a counterfactual where the conflict had not occurred. The selected 11 conflict episodes are listed in Table 6 and represent major conflicts where the two years preceding the conflict were relatively peaceful. ${ }^{19}$

\footnotetext{
18 The results in this paper are qualitatively similar to that in Novta and Pugacheva (2020).

${ }^{19}$ Countries like Nigeria, Chad and Rwanda are not included despite having experienced intensive conflicts because of the difficulty in clearly identifying conflict onset years (i.e. a relatively peaceful period followed by an uptick in conflict).
} 
Table 6. Conflict Episodes

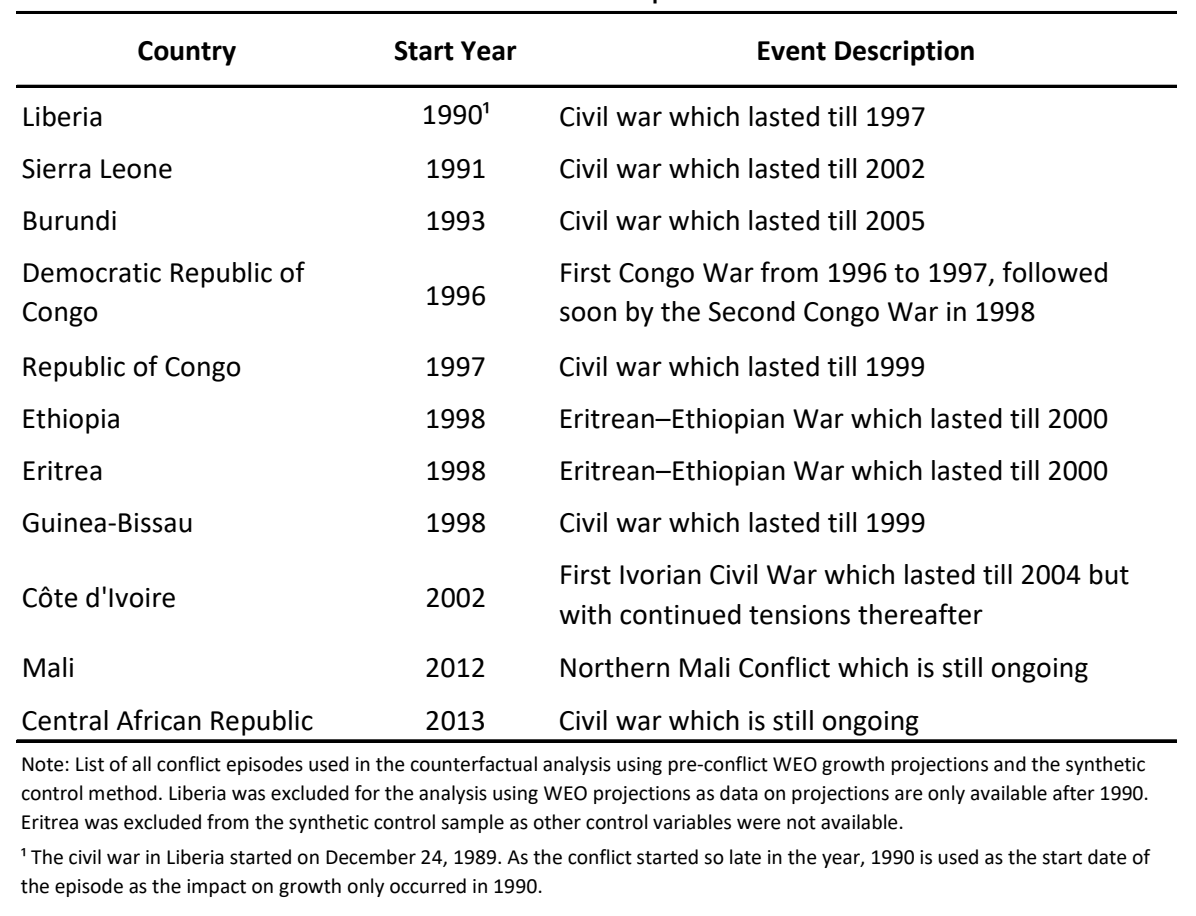

\section{Counterfactual Output Based on WEO Projection}

Every year in October, the IMF projects economic growth for all member countries five years ahead. Data for these projections are available for all vintages going back to 1990 . Comparing actual growth outcomes to projections made before the onset of conflict can help identify the deviation between actual output during conflict episodes and the counterfactual level of output in the absence of conflict. ${ }^{20}$ Specifically, the counterfactual output is computed as:

$$
\hat{y}_{i, T-1+h}=y_{i, T-1} \prod_{j=0}^{h-1}\left(1+g_{T+j}^{W E O}\right) \quad \forall h=1,2 \ldots 5
$$

where $T$ is the year of conflict onset, $h$ is the horizon at which counterfactual output is being computed, $y_{i, T-1}$ is per-capita GDP in the year preceding the conflict onset, and $g_{T+j}^{W E O}$ is preconflict projected growth between time $T+j-1$ and $T+j$. Comparing $\hat{y}_{i, T-1+h}$ to the actual outcome of per-capita GDP provides an estimate of lost output due to conflict.

\section{Counterfactual Output using Synthetic Control Method}

Counterfactual output for the selected conflict episodes is also constructed using the synthetic control method, which involves creating a "synthetic" group for each "treated country"

\footnotetext{
${ }^{20}$ Several studies point to over-optimism in growth projections, which can cause an upward bias in estimates of output loss due to conflict. To control for this bias, WEO projections for all time horizons are adjusted for an average bias (in subSaharan African countries) in non-conflict years.
} 
(where treatment is defined as the conflict episode listed in Table 6). The "synthetic" control group is constructed as a weighted average of the available "donor pool" of countries-i.e., a weighted average of other countries which did not suffer from a major conflict in the same period. The idea is to recreate a synthetic country which matches the observables of the "treated" country that experienced conflict. The weights applied to countries in the donor pool are chosen such that the weighted average of key variables of the synthetic group closely matches the value of the same variables in the "treated" country prior to the outbreak of conflict.

Given the focus of the analysis on economic growth, weights are chosen to match the growth rates in the 4 years prior to the conflict outbreak, and the level of per-capita GDP (at

purchasing power parity), investment rate, the level of openness of the economy, and partner country growth rate in the year prior to the conflict onset. Once the synthetic group has been constructed, the weighted average growth rate of the synthetic group is used to construct a measure of counterfactual output for the "treated" country. This is under the assumption that in the absence of conflict, the conflict-affected country would have experienced growth rates similar to the synthetic group, as it had similar characteristics in the pre-conflict period.

\section{Results}

Figure 13 plots the results of both the counterfactual exercises for each of our episodes. Across all countries, the counterfactual levels of per-capita GDP are significantly higher than realized outcomes. Using forecasts from the IMF World Economic Outlook database, five years after the conflict began, per capita GDP is, on average, 8 percent below its pre-conflict level compared with a projected increase of 7 percent, suggesting a decline in per capita GDP of about 15 percent as a result of the conflict.

These findings are similar to those obtained from the synthetic control approach. The results show that five years into the conflict, the synthetic group saw an increase in per capita GDP of 12 percent on average, compared with a decline of 10 percent in the conflict cases. 
Figure 13: Per-capita GDP Around Conflict Episodes

A. Liberia, 1990

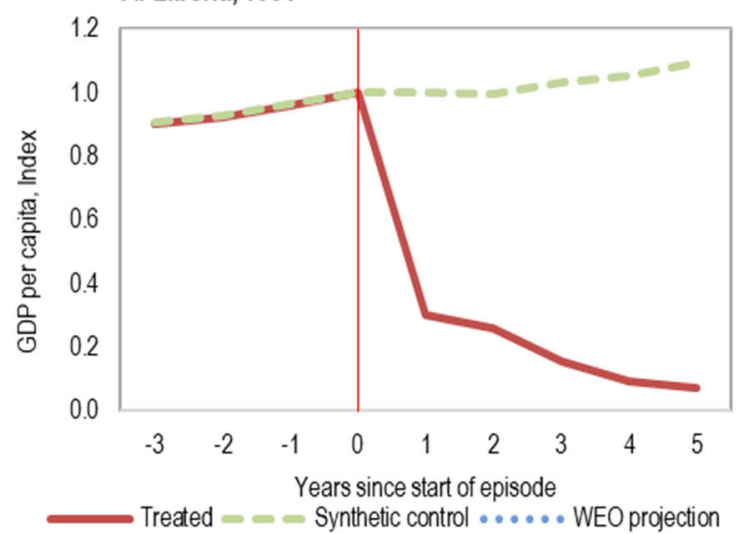

Synthetic groups comprises of Bhutan (weight .04) Botswana (.16) Central African Republic (.12) Equatorial Guinea (.38) Lesotho (.18) Nigeria (.12) C. Burundi, 1993

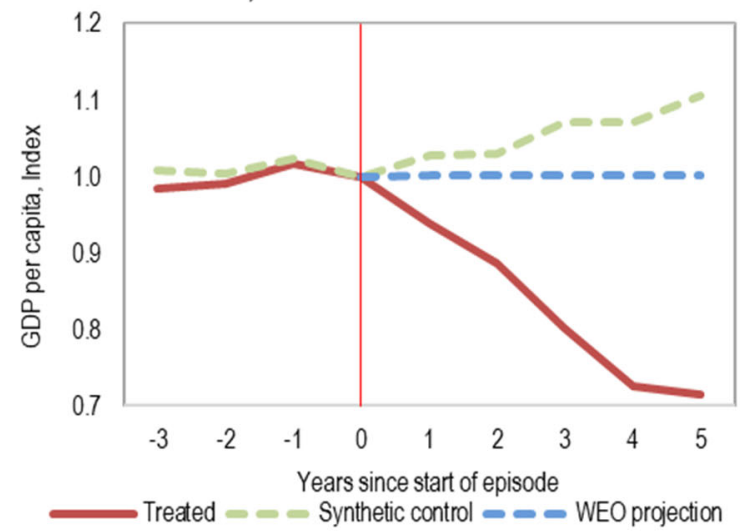

Synthetic groups comprises of Bangladesh (weight .2) Central African Republic (.38) Malawi (.30) Syria (.16)

E. Congo, Rep. of, 1997

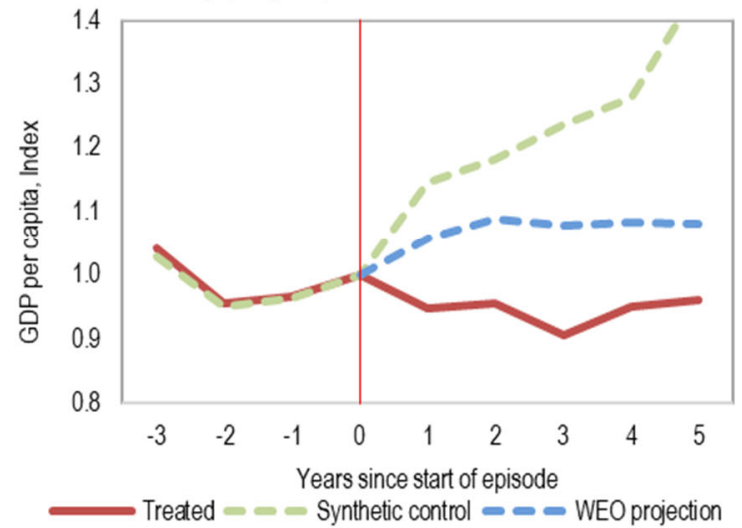

Synthetic groups comprises of Azerbaijan (weight .01) Belanus (.02) Equatorial Guinea (.20) Moldova(.13) Mongolia (.48) Ukraine (.16)
B. Sierra Leone, 1991



Synthetic groups comprises of Albania (weight.11) Bangladesh (.72) Bhutan (.02) Iran (.04) Madagascar (.11)

D. Congo, Dem. Rep. of, 1996

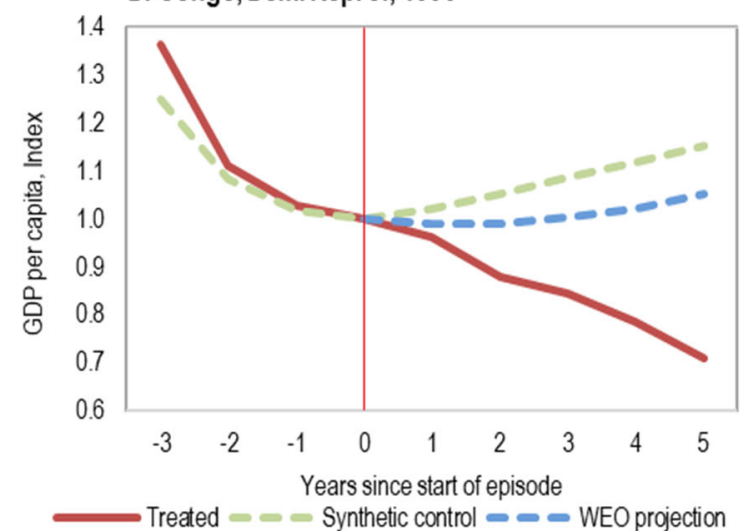

Synthetic groups comprises of Azerbaijan (weight .28) Cameroon (.4) Mongolia (.17) Togo (.12) Yemen (.04)

F. Eritrea, 1998

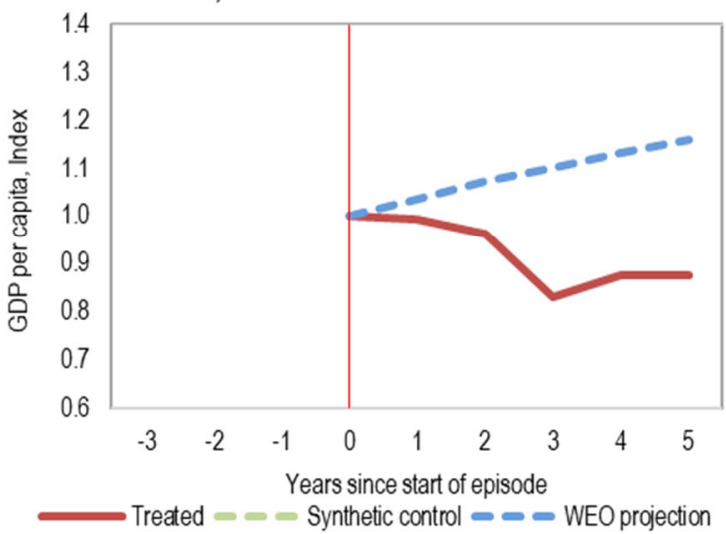




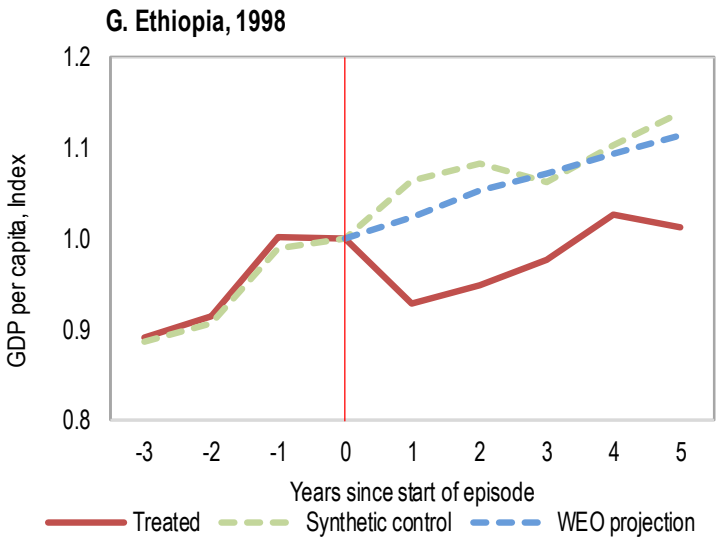

Synthetic groups comprises of Albania (weight .06) Burkina Faso (.04) India (.13) Malawi (.13) Mozambique (.29) Niger (.34) Yemen (.01) I. Cote d'Ivore, 2002

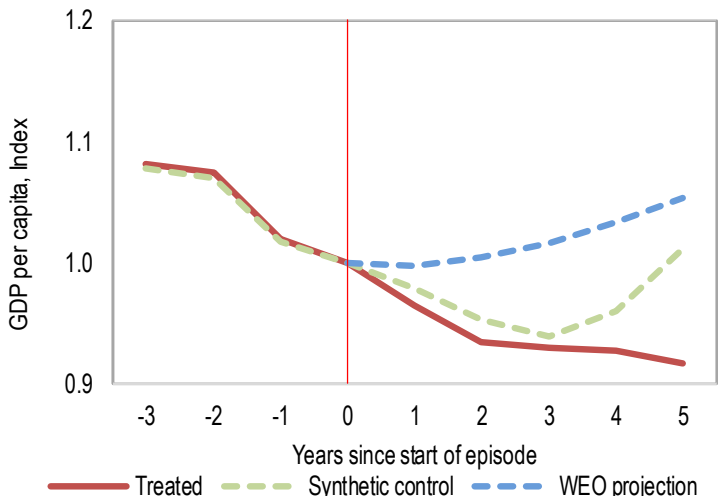

Synthetic groups comprises of Malawi (weight.12) Mauritania (.31) Niger (.11) Seychelles (.17) Zimbabwe (.29)

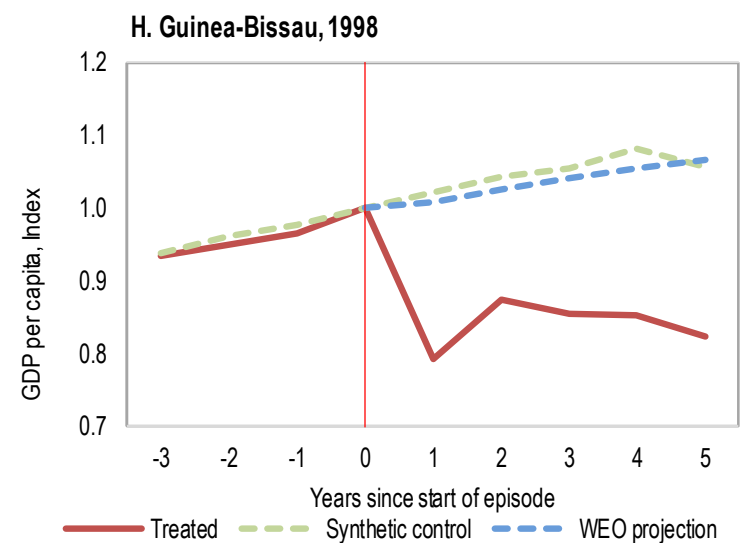

Synthetic groups comprises ofCameroon (.1) India (.18) Madagascar (.26) Mongolia (.34) Mozambique (.02) Suriname (.1)

J. Mali, 2012

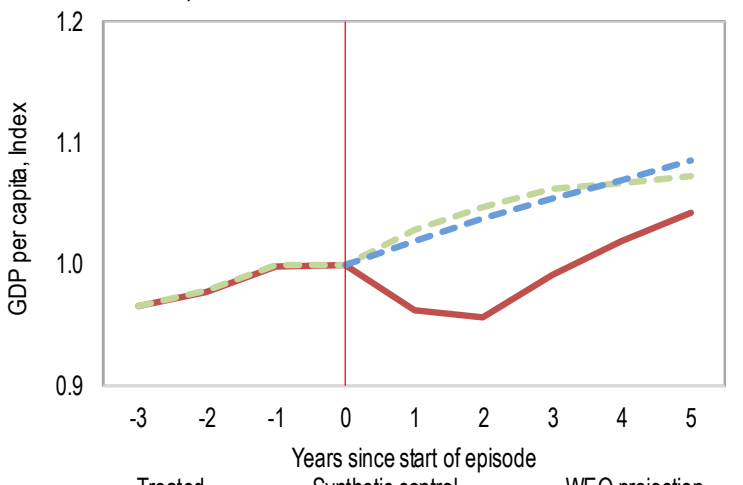

Synthetic groups comprises ofBangladesh (weight.18) Burkina Faso (.01) Burundi (.07) Comoros (.37) Gambia, The (.13) Hait (.01) Malawi (.01) Niger (.13) Zimbabwe .(02)

K. Central African Republic, 2013



Synthetic groups comprises ofBangladesh (weight .29) Burundi (.41) Gambia, The (.02) Haifi (.03) Madagascar (.25)

Source: IMF, World Economic Outlook database, and IMF staff calculations.

Note: Compares the evolution of per-capita GDP around 11 conflict episodes listed in Table 6 to WEO projections before the start of the conflict and to a synthetic control group. WEO projections for per-capita GDP growth were unaivalable for Sierre Leone and Eritrea. However, real GDP growth projections were available, and these were adjsuted for population growth prevailaing before the start of conflict. All countries that were given a weight of more than 1 percentin the synthetic group are noted below each figure.

\section{CInternational Monetary Fund. Not for Redistribution}




\section{Fiscal ImPlications OF CONFLICT}

Conflicts can have substantial effects both on the revenue and expenditure sides of a country's public finances. This limits the government's ability to respond to conflicts in an effective way, thereby aggravating their economic and social costs. On the revenue side, conflicts can reduce collections by disrupting economic activity, destroying part of the tax base, and lowering the efficiency of tax administration.

To examine the fiscal consequences of conflict, including the impact on revenue performance and the composition of government spending, the following model is estimated:

$$
F i s_{i, t}=\beta_{1} F i s_{i, t-1}+\beta_{2} C_{i, t}+\gamma X_{i, t}+\alpha_{i}+\alpha_{t}++\varepsilon_{i t}
$$

where the dependent variable $F i s_{i t}$ represents various fiscal indicators for country $i$ at time $t$ (such as total revenue, military spending, capital expenditure, total expenditure, and fiscal balance), while $F i s_{i, t-1}$ is the lagged dependent variable to capture the persistence in fiscal variables. $C_{i, t}$ is the conflict intensity variable, $X_{i, t}$ is a vector of control variables (including $(\log )$ real GDP per capita, $(\log )$ consumer price index, value added of agriculture sector, natural resources rents, trade openness, and a composite measure of democracy). ${ }^{21} \alpha_{\mathrm{i}}$ and $\alpha_{\mathrm{t}}$ are country and year fixed effects, respectively and $\varepsilon_{i t}$ is the error term.

Equation (4) is estimated using OLS and standard errors are clustered at the country level. The dependent variables are measured in percent of GDP.

\section{Results}

The estimation results for the impact of conflict intensity (constructed from the GED) on total revenue, military expenditure, capital expenditure, current expenditure, and total expenditure are reported in Table 7. For revenues, the coefficient indicates that moving from no conflict to the $75^{\text {th }}$ percentile of the conflict intensity variable implies a reduction in revenue by around 2 percent of GDP (column 1). On the expenditure side, an increase in conflict intensity is associated with about 0.6 percent of GDP higher military spending on average (columns 2-3), while capital expenditures decrease by around the same magnitude0.7 percent of GDP (column 4). Total public spending (column 6), therefore, does not increase significantly during conflicts. This suggests that security concerns lead to a shift in spending from growth-friendly capital expenditures to military spending. Moreover, the net effect of an increase in conflict intensity is thus an increase in the fiscal deficit of about 2 percent of GDP (column 7). ${ }^{22}$

\footnotetext{
${ }^{21}$ In estimating military spending, (log) population and the average of neighboring countries' military spending are also included as additional controls (instead of inflation, agricultural value-added, and natural resources rents), see column 3 of Table 7.

${ }^{22}$ As a robustness check, we also instrument for the contemporaneous conflict intensity variable with lagged values using the difference-GMM and system-GMM methodologies. The results for military spending, capital expenditure and total expenditure are consistent with the baseline.
} 
Table 7. Sub-Saharan Africa: Impact of Conflict on Fiscal Variables, Uppsala GED

\begin{tabular}{|c|c|c|c|c|c|c|c|}
\hline & (1) & $(2)$ & (3) & (4) & (5) & (6) & (7) \\
\hline VARIABLES & $\begin{array}{c}\text { Total } \\
\text { Revenue }\end{array}$ & $\begin{array}{c}\text { Military } \\
\text { Expenditure }\end{array}$ & $\begin{array}{c}\text { Military } \\
\text { Expenditure }\end{array}$ & $\begin{array}{c}\text { Capital } \\
\text { Expenditure }\end{array}$ & $\begin{array}{c}\text { Current } \\
\text { Expenditure }\end{array}$ & $\begin{array}{c}\text { Total } \\
\text { Expenditure }\end{array}$ & Fiscal Balance \\
\hline Dependent variable (lagged) & $\begin{array}{c}0.436 * * * \\
(0.058)\end{array}$ & $\begin{array}{c}0.566 * * * \\
(0.176)\end{array}$ & $\begin{array}{c}0.404 \\
(0.251)\end{array}$ & $\begin{array}{c}0.761^{* * *} \\
(0.050)\end{array}$ & $\begin{array}{c}0.725^{* * *} \\
(0.026)\end{array}$ & $\begin{array}{c}0.660 * * * \\
(0.052)\end{array}$ & $\begin{array}{c}0.346 * * * \\
(0.075)\end{array}$ \\
\hline Conflict intensity & $\begin{array}{c}-2.392 * * * \\
(0.740)\end{array}$ & $\begin{array}{c}0.551 * * \\
(0.228)\end{array}$ & $\begin{array}{c}0.761 * * \\
(0.348)\end{array}$ & $\begin{array}{c}-0.957^{* *} \\
(0.448)\end{array}$ & $\begin{array}{c}0.640 \\
(0.471)\end{array}$ & $\begin{array}{c}0.340 \\
(0.461)\end{array}$ & $\begin{array}{c}-2.678 * * * \\
(0.542)\end{array}$ \\
\hline GDP per capita (lagged) & $\begin{array}{l}-0.396 \\
(0.893)\end{array}$ & $\begin{array}{c}0.058 \\
(0.105)\end{array}$ & $\begin{array}{l}-0.044 \\
(0.117)\end{array}$ & $\begin{array}{c}0.741 \\
(0.650)\end{array}$ & $\begin{array}{c}-1.057^{* *} \\
(0.456)\end{array}$ & $\begin{array}{l}-0.711 \\
(0.641)\end{array}$ & $\begin{array}{l}1.054 * \\
(0.602)\end{array}$ \\
\hline Consumer price index (log) & $\begin{array}{l}-0.368 \\
(0.231)\end{array}$ & $\begin{array}{c}-0.083^{* *} \\
(0.034)\end{array}$ & $\begin{array}{l}-0.071 \\
(0.071)\end{array}$ & $\begin{array}{l}-0.431 \\
(0.325)\end{array}$ & $\begin{array}{l}-0.483^{*} \\
(0.248)\end{array}$ & $\begin{array}{c}-0.640 * * * \\
(0.167)\end{array}$ & $\begin{array}{c}0.315 \\
(0.210)\end{array}$ \\
\hline Agriculture value added/GDP & $\begin{array}{l}-0.026 \\
(0.037)\end{array}$ & $\begin{array}{c}0.001 \\
(0.010)\end{array}$ & & $\begin{array}{l}-0.016 \\
(0.025)\end{array}$ & $\begin{array}{l}-0.048 \\
(0.038)\end{array}$ & $\begin{array}{l}-0.051 \\
(0.031)\end{array}$ & $\begin{array}{c}0.036 \\
(0.040)\end{array}$ \\
\hline Natural resources rents/GDP & $\begin{array}{c}0.160 * * * \\
(0.050)\end{array}$ & $\begin{array}{c}0.009 \\
(0.006)\end{array}$ & & $\begin{array}{c}0.023 \\
(0.026)\end{array}$ & $\begin{array}{c}0.001 \\
(0.036)\end{array}$ & $\begin{array}{c}0.006 \\
(0.046)\end{array}$ & $\begin{array}{c}0.177^{* *} \\
(0.069)\end{array}$ \\
\hline Trade openness (log) & $\begin{array}{c}2.112^{* *} \\
(0.950)\end{array}$ & $\begin{array}{c}0.108 \\
(0.167)\end{array}$ & $\begin{array}{c}0.149 \\
(0.219)\end{array}$ & $\begin{array}{c}0.300 \\
(0.594)\end{array}$ & $\begin{array}{c}1.233^{* *} \\
(0.495)\end{array}$ & $\begin{array}{c}2.095 * * * \\
(0.765)\end{array}$ & $\begin{array}{l}-0.946 * \\
(0.552)\end{array}$ \\
\hline Democracy index & $\begin{array}{c}0.018 * * \\
(0.008)\end{array}$ & $\begin{array}{c}0.001 \\
(0.002)\end{array}$ & $\begin{array}{l}-0.000 \\
(0.002)\end{array}$ & $\begin{array}{l}0.006 * \\
(0.004)\end{array}$ & $\begin{array}{l}-0.010^{*} \\
(0.005)\end{array}$ & $\begin{array}{l}-0.001 \\
(0.006)\end{array}$ & $\begin{array}{l}0.021 * * \\
(0.008)\end{array}$ \\
\hline Population (log) & & & $\begin{array}{c}0.909 \\
(0.788)\end{array}$ & & & & \\
\hline Average military spending of neighbors & & & $\begin{array}{c}0.043 \\
(0.046)\end{array}$ & & & & \\
\hline Country fixed effects & Yes & Yes & Yes & Yes & Yes & Yes & Yes \\
\hline Year fixed effects & Yes & Yes & Yes & Yes & Yes & Yes & Yes \\
\hline Observations & 846 & 842 & 772 & 813 & 847 & 859 & 846 \\
\hline R-squared & 0.850 & 0.746 & 0.676 & 0.779 & 0.881 & 0.872 & 0.468 \\
\hline No. of countries & 39 & 38 & 35 & 39 & 39 & 39 & 39 \\
\hline
\end{tabular}

Note: Dependent variables are various fiscal indicators in percent of GDP for SSA countries. The intensity of conflict variable is the percentile of deeaths as a share of population based on data from Uppsala's Georeferenced Event Dataset (GED). See Annex Table 1 for details on other control variables. All columns are estimated using OLS with country and year fixed effects. Standard errors reported in parentheses are clustered at the country level. $* * *, * *$, and $*$ indicate statistical significance at the 1,5 and 10 percent level, respectively.

These results remain similar when the conflict intensity variable based on the ACD is used (Table 8). Conflict has a statistically significant negative impact on total revenue (column 1). For expenditure, the intensity of conflict is positively associated with military expenses (columns 2-3) and negatively associated with capital expenditure (column 4). Moreover, a major conflict is associated with around 1 percent of GDP deterioration in fiscal balance (column 7).

Looking at the impact of conflict on public debt, the deterioration in the fiscal balance, combined with lower growth, translates into higher debt levels. The ratio of public debt to GDP increases by an average of 9 percentage points during intense conflicts (Table 9, Panel A), which is similar in magnitude to the average annual decline in debt during the Heavily Indebted Poor Countries and Multilateral Debt Relief Initiatives. Focusing on intense-conflict episodes in subSaharan Africa, the public-debt-to-GDP ratio increases 16 percentage points of GDP in the first two years, with the effect increasing to almost 20 percent of GDP by the fifth year (Figure 14).
Figure 14. Sub-Saharan Africa: Cumulative Change in Debt-to-GDP Ratio during Conflict Episodes

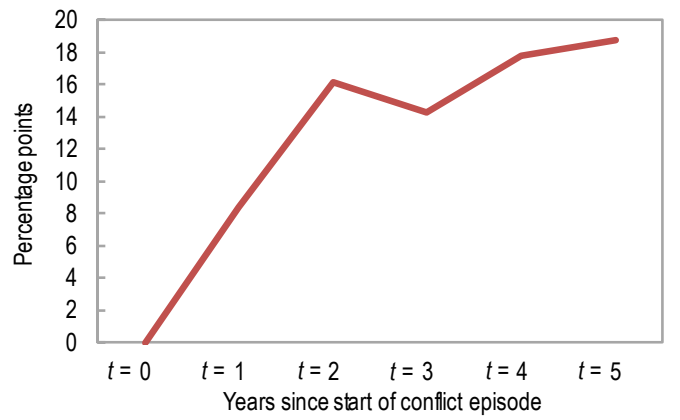

Sources: IMF staff calculations.

Note: Starting years of conflict episodes are defined based on Table 6 . 
Table 8. Sub-Saharan Africa: Impact of Conflict on Fiscal Variables, Uppsala ACD

\begin{tabular}{|c|c|c|c|c|c|c|c|}
\hline & (1) & (2) & (3) & (4) & (5) & (6) & (7) \\
\hline VARIABLES & $\begin{array}{c}\text { Total } \\
\text { Revenue }\end{array}$ & $\begin{array}{c}\text { Military } \\
\text { Expenditure }\end{array}$ & $\begin{array}{c}\text { Military } \\
\text { Expenditure }\end{array}$ & $\begin{array}{c}\text { Capital } \\
\text { Expenditure }\end{array}$ & $\begin{array}{c}\text { Current } \\
\text { Expenditure }\end{array}$ & $\begin{array}{c}\text { Total } \\
\text { Expenditure }\end{array}$ & Fiscal Balance \\
\hline Dependent variable (lagged) & $\begin{array}{c}0.451^{* * *} \\
(0.064)\end{array}$ & $\begin{array}{c}0.607^{* * *} \\
(0.149)\end{array}$ & $\begin{array}{c}0.503^{* *} \\
(0.201)\end{array}$ & $\begin{array}{c}0.706^{* * *} \\
(0.101)\end{array}$ & $\begin{array}{c}0.712^{* * *} \\
(0.035)\end{array}$ & $\begin{array}{c}0.656 * * * \\
(0.054)\end{array}$ & $\begin{array}{c}0.344^{* * *} \\
(0.084)\end{array}$ \\
\hline Conflict intensity & $\begin{array}{l}-0.523 \\
(0.455)\end{array}$ & $\begin{array}{c}0.277^{* *} \\
(0.117)\end{array}$ & $\begin{array}{c}0.361^{* *} \\
(0.171)\end{array}$ & $\begin{array}{c}-0.386 * * * \\
(0.129)\end{array}$ & $\begin{array}{c}0.746^{* * *} \\
(0.201)\end{array}$ & $\begin{array}{c}0.338 \\
(0.358)\end{array}$ & $\begin{array}{c}-0.944 * * * \\
(0.211)\end{array}$ \\
\hline GDP per capita (lagged) & $\begin{array}{c}0.135 \\
(1.100)\end{array}$ & $\begin{array}{c}0.018 \\
(0.104)\end{array}$ & $\begin{array}{l}-0.009 \\
(0.143)\end{array}$ & $\begin{array}{c}0.616 \\
(0.779)\end{array}$ & $\begin{array}{c}-1.001^{* *} \\
(0.435)\end{array}$ & $\begin{array}{l}-0.726 \\
(0.654)\end{array}$ & $\begin{array}{l}1.778^{* *} \\
(0.655)\end{array}$ \\
\hline Consumer price index (log) & $\begin{array}{l}-0.500^{*} \\
(0.274)\end{array}$ & $\begin{array}{l}-0.025 \\
(0.021)\end{array}$ & $\begin{array}{l}-0.005 \\
(0.032)\end{array}$ & $\begin{array}{l}-0.310 \\
(0.237)\end{array}$ & $\begin{array}{l}-0.209 \\
(0.193)\end{array}$ & $\begin{array}{c}-0.642^{* * *} \\
(0.176)\end{array}$ & $\begin{array}{c}0.249 \\
(0.203)\end{array}$ \\
\hline Agriculture value added/GDP & $\begin{array}{l}-0.032 \\
(0.040)\end{array}$ & $\begin{array}{l}-0.001 \\
(0.006)\end{array}$ & & $\begin{array}{l}-0.008 \\
(0.025)\end{array}$ & $\begin{array}{l}-0.027 \\
(0.024)\end{array}$ & $\begin{array}{l}-0.049 \\
(0.030)\end{array}$ & $\begin{array}{c}0.026 \\
(0.041)\end{array}$ \\
\hline Natural resources rents/GDP & $\begin{array}{c}0.138^{* *} \\
(0.051)\end{array}$ & $\begin{array}{c}0.006 \\
(0.006)\end{array}$ & & $\begin{array}{c}0.012 \\
(0.028)\end{array}$ & $\begin{array}{l}-0.010 \\
(0.032)\end{array}$ & $\begin{array}{l}-0.001 \\
(0.045)\end{array}$ & $\begin{array}{l}0.164^{* *} \\
(0.067)\end{array}$ \\
\hline Trade openness (log) & $\begin{array}{l}1.555^{*} \\
(0.768)\end{array}$ & $\begin{array}{c}0.168 \\
(0.101)\end{array}$ & $\begin{array}{c}0.130 \\
(0.148)\end{array}$ & $\begin{array}{c}0.595 \\
(0.537)\end{array}$ & $\begin{array}{c}1.361^{* * *} \\
(0.408)\end{array}$ & $\begin{array}{c}1.990 * * * \\
(0.602)\end{array}$ & $\begin{array}{c}-1.206^{* *} \\
(0.487)\end{array}$ \\
\hline Democracy index & $\begin{array}{c}0.022 * * * \\
(0.008)\end{array}$ & $\begin{array}{l}-0.001 \\
(0.002)\end{array}$ & $\begin{array}{l}-0.002 \\
(0.003)\end{array}$ & $\begin{array}{c}0.006 \\
(0.004)\end{array}$ & $\begin{array}{c}-0.006^{* *} \\
(0.003)\end{array}$ & $\begin{array}{l}-0.002 \\
(0.007)\end{array}$ & $\begin{array}{c}0.025^{* * *} \\
(0.008)\end{array}$ \\
\hline Population (log) & & & $\begin{array}{c}0.316 \\
(0.655)\end{array}$ & & & & \\
\hline Average military spending of neighbors & & & $\begin{array}{c}0.031 \\
(0.033)\end{array}$ & & & & \\
\hline Country fixed effects & Yes & Yes & Yes & Yes & Yes & Yes & Yes \\
\hline Year fixed effects & Yes & Yes & Yes & Yes & Yes & Yes & Yes \\
\hline Observations & 791 & 974 & 997 & 740 & 794 & 811 & 791 \\
\hline R-squared & 0.859 & 0.770 & 0.724 & 0.795 & 0.924 & 0.880 & 0.478 \\
\hline No. of countries & 35 & 35 & 35 & 35 & 35 & 35 & 35 \\
\hline
\end{tabular}

Note: Dependent variables are various fiscal indicators in percent of GDP for SSA countries. The intensity of conflict variable is based on data from Uppsala's Armed Conflict Dataset (ACD). See Annex Table 1 for details on other control variables. All columns are estimated using OLS with country and year fixed effects. Standard errors reported in parentheses are clustered at the country level. ${ }^{* * *},{ }^{* *}$, and ${ }^{*}$ indicate statistical significance at the 1,5 and 10 percent level, respectively.

Table 9. Sub-Saharan Africa: Impact of Conflict on Debt-to-GDP Ratio

\begin{tabular}{|c|c|c|c|c|c|c|c|c|}
\hline \multirow[b]{2}{*}{ VARIABLES } & \multicolumn{4}{|c|}{ Panel A: GED } & \multicolumn{4}{|c|}{ Panel B: ACD } \\
\hline & $(1)$ & $(2)$ & $(3)$ & (4) & $(5)$ & (6) & (7) & $(8)$ \\
\hline Dependent variable (lagged) & $\begin{array}{c}0.892^{* * *} \\
(0.031)\end{array}$ & $\begin{array}{c}0.884^{* * *} \\
(0.041)\end{array}$ & $\begin{array}{c}0.885^{* * *} \\
(0.039)\end{array}$ & $\begin{array}{c}0.886 * * * \\
(0.039)\end{array}$ & $\begin{array}{c}0.884^{* * *} \\
(0.026)\end{array}$ & $\begin{array}{c}0.882 * * * \\
(0.042)\end{array}$ & $\begin{array}{c}0.883 * * * \\
(0.040)\end{array}$ & $\begin{array}{c}0.883 * * * \\
(0.041)\end{array}$ \\
\hline Conflict intensity & $\begin{array}{c}9.259 * * \\
(4.479)\end{array}$ & $\begin{array}{c}10.906 * \\
(5.749)\end{array}$ & $\begin{array}{c}10.491^{*} \\
(5.675)\end{array}$ & $\begin{array}{c}10.605^{*} \\
(5.650)\end{array}$ & $\begin{array}{c}1.534 \\
(1.005)\end{array}$ & $\begin{array}{l}3.820 * \\
(1.891)\end{array}$ & $\begin{array}{c}4.398 * * \\
(2.020)\end{array}$ & $\begin{array}{c}4.615 * * \\
(2.068)\end{array}$ \\
\hline HIPC/MDRI dummy & $\begin{array}{c}-11.013^{* *} \\
(4.202)\end{array}$ & $\begin{array}{c}-10.414^{* *} \\
(4.559)\end{array}$ & $\begin{array}{c}-10.545^{* *} \\
(4.516)\end{array}$ & $\begin{array}{c}-10.360 * * \\
(4.425)\end{array}$ & $\begin{array}{c}-12.032^{* *} \\
(4.817)\end{array}$ & $\begin{array}{c}-11.738^{* *} \\
(5.216)\end{array}$ & $\begin{array}{c}-11.721^{* *} \\
(5.164)\end{array}$ & $\begin{array}{c}-12.008^{* *} \\
(5.201)\end{array}$ \\
\hline Fiscal balance/GDP & & $\begin{array}{c}-0.659 * * * \\
(0.131)\end{array}$ & $\begin{array}{c}-0.656^{* * *} \\
(0.129)\end{array}$ & $\begin{array}{c}-0.662 * * * \\
(0.127)\end{array}$ & & $\begin{array}{c}-0.678^{* * *} \\
(0.120)\end{array}$ & $\begin{array}{c}-0.676^{* * *} \\
(0.125)\end{array}$ & $\begin{array}{c}-0.691 * * * \\
(0.122)\end{array}$ \\
\hline Percent change in REER & & & $\begin{array}{c}-0.302 * * * \\
(0.065)\end{array}$ & $\begin{array}{c}-0.299 * * * \\
(0.067)\end{array}$ & & & $\begin{array}{c}-0.258^{* * *} \\
(0.053)\end{array}$ & $\begin{array}{c}-0.277^{* * *} \\
(0.056)\end{array}$ \\
\hline Per capita GDP (log) & & & & $\begin{array}{c}1.475 \\
(2.888)\end{array}$ & & & & $\begin{array}{c}-0.115 \\
(3.087)\end{array}$ \\
\hline Observations & 1,132 & 965 & 948 & 948 & 1,569 & 938 & 913 & 891 \\
\hline R-squared & 0.920 & 0.925 & 0.927 & 0.927 & 0.919 & 0.927 & 0.928 & 0.930 \\
\hline No. of countries & 41 & 41 & 40 & 40 & 39 & 39 & 37 & 36 \\
\hline
\end{tabular}




\section{Non-linear Effects}

As was the case for economic growth, the fiscal effects of conflict stem mainly from highintensity conflicts as reported in Table 10. When conflict intensity is in the bottom two quartiles, fiscal performance is not significantly different from that in the non-conflict case. However, as conflict intensity moves to the third and fourth quartile, the impact becomes statistically significant. For revenues, when conflict intensity increases to the top two quartiles, total revenue decreases by about 2 percent of GDP (column 1). On the expenditure side, military spending is around 0.6 percent of GDP higher for conflicts in top quartile (columns 2-3), while capital expenditure decreases by about 0.7 percent of GDP for the same category of conflicts (column 4).

\begin{tabular}{|c|c|c|c|c|c|c|c|}
\hline VARIABLES & $\begin{array}{c}(1) \\
\text { Total } \\
\text { Revenue }\end{array}$ & $\begin{array}{c}(2) \\
\text { Military } \\
\text { Expenditure }\end{array}$ & $\begin{array}{c}(3) \\
\text { Military } \\
\text { Expenditure }\end{array}$ & $\begin{array}{c}\text { (4) } \\
\text { Capital } \\
\text { Expenditure }\end{array}$ & $\begin{array}{c}(5) \\
\text { Current } \\
\text { Expenditure }\end{array}$ & $\begin{array}{c}(6) \\
\text { Total } \\
\text { Expenditure }\end{array}$ & $\begin{array}{c}(7) \\
\text { Fiscal Balance } \\
\end{array}$ \\
\hline Dependent variable (lagged) & $\begin{array}{c}0.438^{* * *} \\
(0.057)\end{array}$ & $\begin{array}{c}0.553^{* * *} \\
(0.179)\end{array}$ & $\begin{array}{c}0.385 \\
(0.255)\end{array}$ & $\begin{array}{c}0.762 * * * \\
(0.051)\end{array}$ & $\begin{array}{c}0.722 * * * \\
(0.026)\end{array}$ & $\begin{array}{c}0.658^{* * *} \\
(0.052)\end{array}$ & $\begin{array}{c}0.344^{* * *} \\
(0.074)\end{array}$ \\
\hline Excluded group: No conflict & & & & & & & \\
\hline Conflict: 1st Quartile & $\begin{array}{c}0.262 \\
(0.644)\end{array}$ & $\begin{array}{c}0.028 \\
(0.058)\end{array}$ & $\begin{array}{l}-0.009 \\
(0.088)\end{array}$ & $\begin{array}{c}0.097 \\
(0.386)\end{array}$ & $\begin{array}{l}-0.349 \\
(0.415)\end{array}$ & $\begin{array}{l}-0.100 \\
(0.614)\end{array}$ & $\begin{array}{c}0.488 \\
(0.979)\end{array}$ \\
\hline Conflict: 2nd Quartile & $\begin{array}{c}-1.170 * \\
(0.591)\end{array}$ & $\begin{array}{l}-0.094 \\
(0.089)\end{array}$ & $\begin{array}{l}-0.148 \\
(0.132)\end{array}$ & $\begin{array}{l}-0.215 \\
(0.360)\end{array}$ & $\begin{array}{l}-0.364 \\
(0.347)\end{array}$ & $\begin{array}{l}-0.454 \\
(0.443)\end{array}$ & $\begin{array}{l}-0.341 \\
(0.612)\end{array}$ \\
\hline Conflict: 3rd Quartile & $\begin{array}{c}-1.720 * * * \\
(0.595)\end{array}$ & $\begin{array}{c}0.143 \\
(0.111)\end{array}$ & $\begin{array}{c}0.145 \\
(0.124)\end{array}$ & $\begin{array}{c}-0.819 * * \\
(0.352)\end{array}$ & $\begin{array}{c}0.101 \\
(0.346)\end{array}$ & $\begin{array}{l}-0.234 \\
(0.422)\end{array}$ & $\begin{array}{c}-1.460 * * \\
(0.616)\end{array}$ \\
\hline Conflict: 4th Quartile & $\begin{array}{c}-1.814^{* * *} \\
(0.635)\end{array}$ & $\begin{array}{c}0.514^{* *} \\
(0.208)\end{array}$ & $\begin{array}{c}0.665 * * \\
(0.299)\end{array}$ & $\begin{array}{c}-0.692 * \\
(0.402)\end{array}$ & $\begin{array}{c}0.566 \\
(0.441)\end{array}$ & $\begin{array}{c}0.355 \\
(0.476)\end{array}$ & $\begin{array}{c}-2.107^{* * *} \\
(0.497)\end{array}$ \\
\hline Country fixed effects & Yes & Yes & Yes & Yes & Yes & Yes & Yes \\
\hline Year fixed effects & Yes & Yes & Yes & Yes & Yes & Yes & Yes \\
\hline Observations & 846 & 842 & 772 & 813 & 847 & 859 & 846 \\
\hline R-squared & 0.851 & 0.748 & 0.679 & 0.780 & 0.881 & 0.872 & 0.469 \\
\hline No. of countries & 39 & 38 & 35 & 39 & 39 & 39 & 39 \\
\hline
\end{tabular}

\section{CONCLuSION}

After declining in the early 2000 s, there has been an uptick in conflicts in recent years in subSaharan Africa. The analysis highlights the large economic costs imposed by conflict. Counterfactual analysis suggests that real GDP per capita may be as much as 20 percent lower five years after the start of a conflict compared with a non-conflict scenario. In addition, conflicts put pressure on public finances by reducing revenue, shifting the composition away from capital to military spending, and increasing public debt - further jeopardizing socioeconomic stability and increasing the risk of prolonged conflict.

Given these large costs, it is imperative to prevent the occurrence of conflicts. As earlier literature has shown, several economic and structural factors, such as low-income levels, poor growth outcomes, weak state capacity, and inequality of opportunity-especially across ethnic, religious, and regional groups - are associated with a higher likelihood of conflict. Addressing these challenges will help to prevent conflicts (United Nations and World Bank, 
2018). For countries in conflict, efforts should focus on limiting the loss of human and physical capital, including by protecting social and development spending, and on trying to maintain well-functioning institutions to lessen the harmful long-term economic effects of conflict. While this may be especially challenging given fiscal pressures, well-targeted and coordinated humanitarian aid and concessional external assistance can help to create room to respond to the ravaging effects of conflicts. Moreover, external assistance may also be essential for countries suffering from the spillover effects of conflicts, in order to protect displaced populations and alleviate the economic and social strains often generated in host countries. 


\section{REFERENCES}

Baranyi, S., P. Beaudet, and U. Locher. 2011. "Conflict, Security, and Development." World Development Report: 342-349.

Barrett, Philip. 2018. "The Fiscal Cost of Conflict: Evidence from Afghanistan 2005-2016." IMF Working Paper No. 18/204.

Bircan, C., T. Brück, and M. Vothknecht. 2017. "Violent Conflict and Inequality." Oxford Development Studies, 45(2), 125-144.

Blomberg, S. Brock and Hess, Gregory D. and Orphanides, Athanasios, 2004. "The Macroeconomic Consequences of Terrorism." Journal of Monetary Economics 51 (5): 1007-1032.

Cerra, V., and S. C. Saxena, 2008. "Growth dynamics: The myth of economic recovery." American Economic Review 98(1): 439-457.

Cevik, S., and J. Ricco. 2015. "Fiscal Consequences of Terrorism.” IMF Working Paper No. $15 / 225$.

Collier, Paul. 1999. "On the economic consequences of civil war." Oxford Economic Papers $51(1): 168-183$.

Collier, P., and N. Sambanis. 2002. "Understanding Civil War: A New Agenda." Journal of Conflict Resolution 46 (1): 3-12.

Gomez, M., A. Christensen, Y. Araya, and N. Harild. 2010. “The Impacts of Refugees on Neighboring Countries: A Development Challenge." World Development Report 2011 Background Note, World Bank, Washington, DC.

Gupta, S., B. Clements, R. Bhattacharya, and S. Chakravarti, 2004. "Fiscal consequences of armed conflict and terrorism in low-and middle-income countries.” European Journal of Political Economy 20 (2): 403-421.

Hegre, H., and N. Sambanis. 2006. "Sensitivity Analysis of Empirical Results on Civil War Onset." Journal of Conflict Resolution 50 (4): 508-35.

International Monetary Fund (IMF). 2019. Regional Economic Outlook: Sub-Saharan Africa. Chapter 2, Washington, D.C, April.

Novta, N., and E. Pugacheva. 2020. “The Macroeconomic Costs of Conflict.”, IMF Working Paper No.20/110.

Mueller, H., and J. Tobias. 2016. "The cost of violence: Estimating the economic impact of conflict." International Growth Centre.

Mueller, H., L. Piemontese, and A. Tapsoba. 2017. "Recovery from conflict: lessons of success.” World Bank Policy Research Working Paper 7970.

Murdoch, J. C., and T. Sandler. 2002. "Economic Growth, Civil Wars and Spatial Spillovers." Journal of Conflict Resolution 46 (1): 91-110.

Qureshi, M. S. 2013. “Trade and Thy Neighbor's War.” Journal of Development Economics 105 (C): 178-95. 
Rother, B., G. Pierre, D. Lombardo, R. Herrala, P. Toffano, E., Roos, A. G. Auclair, and K. Manasseh. 2016. "The Economic Impact of Conflicts and the Refugee Crisis in the Middle East and North Africa." IMF Staff Discussion Note 16/8, International Monetary Fund, Washington, DC.

Straus, S. 2012. "Wars Do End! Changing Patterns of Political Violence in Sub-Saharan Africa." African Affairs 111.443: 179-201.

Sundberg, R., and E. Melander. 2013. "Introducing the UCDP Georeferenced Event Dataset." Journal of Peace Research 50 (4): 523-32.

United Nations and World Bank. 2018. "Pathways for Peace: Inclusive Approaches to Preventing Violent Conflict." https://openknowledge.worldbank.org/handle/10986/28337.

World Bank. 2016. “An Assessment of Uganda's Progressive Approach to Refugee Management." World Bank, Washington, DC. 
Annex Table 1. Data Sources

\begin{tabular}{|c|c|c|}
\hline & \multirow[b]{2}{*}{ Description } & \multirow[b]{2}{*}{ Sources } \\
\hline Variable & & \\
\hline Agriculture, value added & In percent of GDP & WB, World Development Indicators \\
\hline Capital account openness & Index (high values: more open) & Chinn and Ito (2006)" \\
\hline Capital and current expenditure & In billions of national currency & IMF, WEO database \\
\hline Revenues & In billions of national currency & IMF, WEO database \\
\hline Consumer price index (CPI) & Index & IMF, WEO and INS databases \\
\hline Exchange rate regime (de facto) & $\begin{array}{l}\text { Index (1=hard or conventional peg; } 2=\text { basket } \\
\text { peg/band/crawl/managed float; } 3=\text { free float). }\end{array}$ & Ghosh, Ostry, and Qureshi $(2015)^{21}$ \\
\hline Fiscal balance & In percent of GDP & IMF, WEO database \\
\hline GDP per capita & Log & IMF, WEO database, Penn World Tables 9.0 \\
\hline Gross debt & In percent of GDP & IMF, WEO database, FAD Database \\
\hline HIPC/MDRI & Dummy ( 1 if there is a HIPC/MDRI disbursment) & IMF and Worldbank \\
\hline Human capital & Index & Penn World Tables 9.0 based on Barro-Lee \\
\hline Institutional quality index & $\begin{array}{l}\text { Average of bureaucracy quality, corruption, } \\
\text { democratic accountability, investment profile, and } \\
\text { law and order (high values indicate better quality) }\end{array}$ & International Country Risk Guide \\
\hline Military spending & US Dollars & Stockholm International Peace Research Institute (SIPRI) \\
\hline Nominal GDP & In billions (USD and national currency) & IMF, WEO database \\
\hline Poluation & Number & IMF, WEO database, and Penn World Tables 9.0 \\
\hline Price of investment & Index & Penn World Tables 9.0 \\
\hline Real effective exchange rate (REER) & Percent change & IMF, WEO database \\
\hline Real GDP & In billions of national currency & IMF, WEO database \\
\hline Real GDP growth & In percent & IMF, WEO database, Penn World Tables 9.0 \\
\hline Real GDP growth in trading partners & In percent & IMF, WEO database \\
\hline Real GDP per capita & In PPP terms & IMF, WEO database, Penn World Tables 9.0 \\
\hline Terms of trade of goods & Index & IMF, WEO database \\
\hline Total exports & Percent change & Penn World Tables 9.0 \\
\hline Total factor productivity & Index & IMF, 2018 \\
\hline Total investment & In percent of GDP & IMF, WEO database, Penn World Tables 9.0 \\
\hline Total natural resources rents & In percent of GDP & WB, World Development Indicators \\
\hline Trade openness & Sum of exports and imports, in percent of GDP & IMF, WEO database \\
\hline \multicolumn{3}{|c|}{ 1/ Chinn, M., and H. Ito, 2006, "What Matters for Financial Development? Capital Controls, Institutions, and Interactions," Journal of Development Economics, 81 (1): 163 } \\
\hline \multirow{2}{*}{\multicolumn{3}{|c|}{$\begin{array}{l}\text { 2/ Ghosh, A., J. Ostry, and M. Qureshi, 2015, "Exchange Rate Management and Crisis Susceptibility: A Reassessment," IMF Economic Review, } 63 \text { (1): 238-276. } \\
\text { Annex Table 2. Country Coverage }\end{array}$}} \\
\hline & & \\
\hline Group & \multicolumn{2}{|c|}{ Countries } \\
\hline Oil exporters & \multicolumn{2}{|c|}{ Angola, Cameroon, Chad, Republic of the Congo, Equatorial Guinea, Gabon, Nigeria, South Sudan } \\
\hline Other resource intensive & \multicolumn{2}{|c|}{$\begin{array}{l}\text { Botswana, Burkina Faso, Central African Republic, Democratic Republic of the Congo, Ghana, Guinea, } \\
\text { Liberia, Mali, Namibia, Niger, Sierra Leone, South Africa, Tanzania, Zambia, Zimbabwe }\end{array}$} \\
\hline Non-resource intensive & \multicolumn{2}{|c|}{$\begin{array}{l}\text { Benin, Burundi, Cabo Verde, Comoros, Côte d'Ivoire, Eritrea, Ethiopia, The Gambia, Guinea-Bissau, Kenya, } \\
\text { Lesotho, Madagascar, Malawi, Mauritius, Mozambique, Rwanda, Senegal, Seychelles, eSwatini, São Tomé } \\
\text { and Príncipe, Togo, Uganda }\end{array}$} \\
\hline Central Africa & \multicolumn{2}{|c|}{$\begin{array}{l}\text { Angola, Cameroon, Central African Republic, Chad, Republic of the Congo, Democratic Republic of the } \\
\text { Congo, Equatorial Guinea, Gabon, São Tomé and Príncipe }\end{array}$} \\
\hline Western Africa & \multicolumn{2}{|c|}{$\begin{array}{l}\text { Benin, Burkina Faso, Cabo Verde, Côte d'Ivoire, Guinea, Guinea-Bissau, Liberia, Mali, Niger, Nigeria, } \\
\text { Senegal, Sierra Leone, Togo }\end{array}$} \\
\hline Eastern Africa & \multicolumn{2}{|c|}{$\begin{array}{l}\text { Burundi, Comoros, Eritrea, Ethiopia, Kenya, Madagascar, Malawi, Mauritius, Mozambique, Rwanda, South } \\
\text { Sudan, Seychelles, Tanzania,Uganda, Zambia, Zimbabwe }\end{array}$} \\
\hline Southern Africa & \multicolumn{2}{|l|}{ eSwatini, Lesotho, Namibia, South Africa } \\
\hline Sahel & \multicolumn{2}{|l|}{ Burkina Faso, Cameroon, Chad, Mali, Niger, Nigeria } \\
\hline
\end{tabular}

\section{CInternational Monetary Fund. Not for Redistribution}

